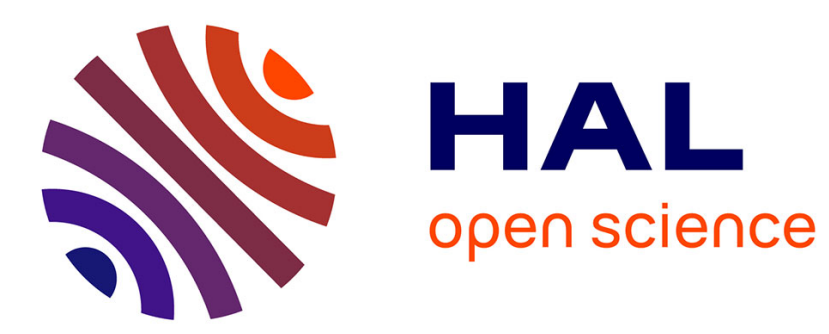

\title{
Structural diffusion properties of two atypical Dps from the cyanobacterium Nostoc punctiforme disclose interactions with ferredoxins and DNA
}

Vamsi Moparthi, Satish Babu Moparthi, Christoph Howe, Patrícia Raleiras, Jérôme Wenger, Karin Stensjö

\section{To cite this version:}

Vamsi Moparthi, Satish Babu Moparthi, Christoph Howe, Patrícia Raleiras, Jérôme Wenger, et al.. Structural diffusion properties of two atypical Dps from the cyanobacterium Nostoc punctiforme disclose interactions with ferredoxins and DNA. Biochimica biophysica acta (BBA) - Bioenergetics, 2019, 1860 (10), pp.148063. 10.1016/j.bbabio.2019.148063 . hal-02280937

\section{HAL Id: hal-02280937 \\ https://hal.science/hal-02280937}

Submitted on 20 Apr 2020

HAL is a multi-disciplinary open access archive for the deposit and dissemination of scientific research documents, whether they are published or not. The documents may come from teaching and research institutions in France or abroad, or from public or private research centers.
L'archive ouverte pluridisciplinaire HAL, est destinée au dépôt et à la diffusion de documents scientifiques de niveau recherche, publiés ou non, émanant des établissements d'enseignement et de recherche français ou étrangers, des laboratoires publics ou privés. 
Structural diffusion properties of two atypical Dps from Nostoc punctiforme disclose interactions with ferredoxins and DNA

Vamsi K Moparthi ${ }^{1,3 *}$, Satish Babu Moparthi ${ }^{2,4}$, Christoph Howe ${ }^{1}$, Patrícia Raleiras ${ }^{1,5}$, Jerome Wenger $^{2}$ and Karin Stensjo ${ }^{*}$

1. Department of Chemistry-Ångström Laboratory, Uppsala University, SE - 75120 Uppsala, Sweden

2. Aix Marseille Univ, CNRS, Centrale Marseille, Institut Fresnel, Marseille, France.

3. Present address: Department of Physics, Chemistry and Biology, Division of Chemistry, Linköping University, SE-58183 Linköping, Sweden.

4. Present address: Membrane Biochemistry and Transport, Institute Pasteur, 28 rue du Dr Roux, 75015, Paris, France.

5. Present address: Medicago AB, Danmark Berga 13, SE-75598 Uppsala, Sweden

*For correspondence, Vamsi K Moparthi, E-mail: vamsi.moparthi@ifm.liu.se, Tel: (+46) 013284671, and Karin Stensjö, E-mail: karin.stensjo@kemi.uu.se, Tel. (+46) 018-471-6586; Fax (+46) 018-471-6844;

\title{
Highlights
}

- The dodecamer stability of the two atypical NpDps are $\mathrm{pH}$ dependent.

- Both NpDps4 and NpDps5 show DNA binding properties.

- Both NpDps4 and NpDps5 show binding properties upon interaction with NpFdx proteins.

- NpDps5, with structural similarities to bacterioferritins, is also related to Dps proteins, due to its dodecameric structure and DNA binding ability.

\begin{abstract}
Ferritin-like proteins Dps (DNA-binding protein from starved cells) store iron and play a key role in the iron homeostasis in bacteria, yet their iron releasing machinery remains largely unexplored. The electron donor proteins that may interact with Dps and promote the mobilization of the stored iron have hitherto not been identified. Here, we investigate the binding capacity of the two atypical Dps proteins NpDps4 and NpDps5 from Nostoc punctiforme to isolated ferredoxins. We report NpDps-ferredoxin interactions by fluorescence correlation spectroscopy (FCS) and fluorescence resonance energy transfer (FRET) methods. Dynamic light scattering, size exclusion chromatography and native gel electrophoresis results show that NpDps4 forms a dodecamer at both $\mathrm{pH} 6.0$ and $\mathrm{pH} 8.0$, while NpDps5 forms a dodecamer only at $\mathrm{pH}$ 6.0. In addition, FCS data clearly
\end{abstract}


reveal that the non-canonical NpDps5 interacts with DNA at $\mathrm{pH}$ 6.0. Our spectroscopic analysis shows that $[\mathrm{Fe}-\mathrm{S}]$ centers of the three recombinantly expressed and isolated ferredoxins are properly incorporated and are consistent with their respective native states. The results support our hypothesis that ferredoxins could be involved in cellular iron homeostasis by interacting with Dps and assisting the release of stored iron.

\title{
Keywords
}

Dps; FRET; FCS; Nostoc puntiforme; Ferredoxins; DLS; Ferritin like proteins

\begin{abstract}
Abbreviations
Dps, DNA-binding proteins; DLS, dynamic light scattering; FRET, fluorescence resonance energy transfer; FCS, fluorescence correlation spectroscopy (FCS); EPR, electron paramagnetic resonance; PSI, photosystem I; Fdx, ferredoxins; EMSA, electrophoretic mobility shift assay; SDS-PAGE, sodium dodecyl sulfate-polyacrylamide gel electrophoresis; NpFdx, Dps in Nostoc punctiforme; DNA, deoxyribonucleic acid; ds, double stranded
\end{abstract}

\section{Introduction}

Iron metabolism is thought to be one of the very early important acquisitions in the origin of life, as iron is one of the elements that is required for cells to survive and to be functionally active $[1,4,36$, 54]. Iron is usually found in two interconvertible oxidation states, $\mathrm{Fe}^{2+}$ and $\mathrm{Fe}^{3+}$. However, $\mathrm{Fe}^{2+}$ can oxidize to $\mathrm{Fe}^{3+}$ in the presence of $\mathrm{O}_{2} . \mathrm{Fe}^{3+}$ then forms iron hydroxide and precipitates, thus limiting its availability to cells. The oxidation of $\mathrm{Fe}^{2+}$ by $\mathrm{H}_{2} \mathrm{O}_{2}$ produces reactive oxygen species (ROS) [1], which damage crucial cell components like DNA, enzymes, and lipids. Therefore, intracellular iron homeostasis needs to be tightly regulated. Prokaryotes and eukaryotes use a family of proteins called ferritin-like proteins to regulate free $\mathrm{Fe}^{2+}$ concentration in the cytosol [35], found in all three domains of life. In bacteria, there are three types of ferritin-like proteins: ferritins (Ftn), bacterioferritins (Bfr), and DNA-binding proteins from starved cells (Dps) [4, 20]. All ferritin-like proteins oxidize $\mathrm{Fe}^{2+}$ to $\mathrm{Fe}^{3+}$ at their ferroxidase centers (FOC), and store the iron as a ferric oxyhydroxide mineral core [20]. Ftn and Bfr are large protein multi-structures (24-mer) that store up to $4500 \mathrm{Fe}$ ions, while Dps are dodecameric (12-mer) proteins that can store about $500 \mathrm{Fe}$ ions. The common working hypothesis is that under low iron conditions, the ferric mineral core is reduced to 
soluble $\mathrm{Fe}^{2+}$, which is released to be utilized by the cell $[32,46,48,60,63]$. This reduction step is crucial for the stored iron to re-enter the metabolism, but unfortunately, little is known about this process, and the identity of the donor that assists electron transfer into Dps is unrevealed.

Numerous studies in various bacteria have shown that Dps homologs exhibit efficient DNA protection, against damage by reactive oxygen species, partly by direct physical binding of DNA $[38,65,44,16,27,58,12]$. Therefore, DNA binding activity is considered as one of the characteristic features of Dps proteins. In contrast, mechanical DNA protection is not one of the core functions of Bfr.

Dps proteins are ubiquitously present in cyanobacteria, where they play a major role in tolerance to oxidative stress, peroxide detoxification, prevention of DNA damage and maintaining the iron homeostasis [34, 23, 41, 37]. Unlike most other prokaryotes, which encode a single Dps, there are five genes annotated as ferritin-like proteins in the multicellular, heterocyst-forming cyanobacterium Nostoc punctiforme sp. ATCC 29133 (from here on N. punctiforme) [39]. We have previously asserted that these proteins co-exist, and named them NpDps1, NpDps2, NpDps3, NpDps4 and NpDps5 [41]. In a phylogenetic analysis it was shown that NpDps1-3 grouped into distinct clades of typical Dps proteins, while both NpDps4 and NpDps5 clustered with noncanonical groups of ferritin-like proteins. One atypical feature of NpDps4 was the unusual ligand sphere of the FOC, also identified in e.g DpsA-Te from Thermosynechococcus elongatus [50, 23]. NpDps5 clustered with, and shared structural features with Bfr, such as harboring the FOCs within the monomers [23]. NpDps5 has been identified as involved in light tolerance in N. punctiforme, and an increase in NpDps5 abundance was shown to enhance tolerance to hydrogen peroxide [37], likely due to is role in iron regulation [41]. The functional roles of NpDps4 have not yet been explored. NpDps5 and NpDps4 are associated with a specific type of cell, the heterocyst, as demonstrated by transcriptional and proteomics studies [45, 23]. Heterocysts are formed during nitrogen-depleted conditions in some filamentous cyanobacteria and exhibit an intracellular microoxic condition that enable nitrogen fixation [5]. The core enzymes involved in heterocyst metabolism are iron-dependent and $\mathrm{O}_{2}$ sensitive. Our hypothesis is that NpDps4 and NpDps5 are involved in the strict control of iron and $\mathrm{O}_{2}$ levels in heterocysts.

As mentioned earlier, the chemistry behind the release of ferrous iron from the mineralized iron core of both Bfrs and Dps is largely unknown. This study aimed to identify electron transfer proteins that interact with the atypical NpDps4, and the bacterioferritin-like, NpDps5. Ferredoxins (Fdxs) are soluble electron transfer proteins found ubiquitously in biological organisms. They possess a highly negative redox potential and use their [Fe-S] (iron-sulfur) clusters to act as electron distributors in various metabolic pathways. Fdxs can be classified according to their [Fe-S] clusters, like [2Fe-2S], 
[3Fe-4S] and [4Fe-4S], and to the organisms in which they were first isolated [56]. Cyanobacteria strains often have a large number of Fdxs that act as electron donors in photosynthesis, oxidative and metal stress responses and in heterocyst specific metabolism [30, 18, 8, 52]. While clearly being of physiological importance, the biochemical characterization of the Fdxs in cyanobacteria is still insufficient.

Fdxs have also been suggested to be involved in $\mathrm{Fe}^{2+}$ release Bfr by direct protein-protein interaction [47], and a Fdx from Pseudomonas aeruginosa has been shown to interact with, and reduce, the iron core of $\mathrm{PaBfr}$ in vitro $[64,24]$. The interaction of $\mathrm{Fdx}$ and $\mathrm{Bfr}$ is thus established, but the proteinprotein interactions that allow the reduction of the iron-core of Dps are still not known. Our intention with this study was to reveal if Fdxs interact with the two non-canonical Dps proteins of $N$. punctiforme. Despite the advancements in defining the roles of NpDps proteins in various cellular processes, many questions, especially concerning non-canonical Dps proteins, remain unanswered. The crystal structures of a number of Dps proteins have been resolved [65, 29], but the biophysical structural diffusional properties of Dps proteins are still unknown. Here fluorescence correlation spectroscopy (FCS) and fluorescence resonance energy transfer (FRET) has been used to determine whether Dps proteins and Fdxs are interacting or not. In addition, we also explored the possible interaction with DNA, and the multimerization properties of NpDps4 and NpDps5 under various conditions.

\section{Materials and methods}

\section{Bacterial strains, media and growth conditions}

This research study was carried out with the heterocyst-forming cyanobacterium Nostoc punctiforme strain ATCC 29133-S (known as UCD 153) [13], Escherichia coli (E. coli) DH5 $\alpha$ strain and E. coli BL21(DE3) strain (Table 1). E. coli cells were grown aerobically at $37^{\circ} \mathrm{C}$ and $200 \mathrm{rpm}$ in LB (Luria - Bertani) medium. For solid media, $1.5 \%$ agar (Noble agar, BD, Difco, Franklin Lakes, NJ, USA) was added. $50 \mu \mathrm{g} \mathrm{mL}^{-1}$ ampicillin was added both in solid and liquid LB media. Cyanobacteria were grown in BG11 [49] without the addition of $\mathrm{NaNO}_{3}$, at $30{ }^{\circ} \mathrm{C}$ and $25-40 \mu \mathrm{mol}$ photons $\mathrm{m}^{-2} \mathrm{~s}^{-1}$ in $100 \mathrm{~mL}$ E-flasks under shaking at $100 \mathrm{rpm}$, or in $250 \mathrm{~mL}$ - $400 \mathrm{~mL}$ E-flasks under aeration and stirring. For solid media, 1\% agar (Noble agar, BD, Difco, Franklin Lakes, NJ, USA) was used. Chlorophyll $a$ measurements and light microscopy (Axiostar, ZEISS) on cultures were performed regularly. Cells were harvested by centrifugation and cell pellets were frozen in liquid nitrogen and stored at $-80^{\circ} \mathrm{C}$, until further investigation. 
Table 1. Bacterial strains used in this work

\begin{tabular}{|c|c|c|}
\hline rial strain & type and information & ence/source \\
\hline richia coli strain DH5 $\alpha$ & $\begin{array}{l}\text { Delta M15 Delta(lacZYA-argF) U169 recA1 end } \\
7(r K-m K+) \text { supE44 thi-1 gyrA96 relA1 }\end{array}$ & \\
\hline richa coli strain BL21(DE3) & 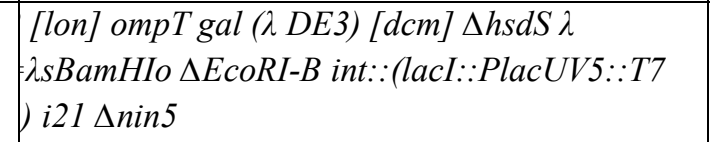 & \\
\hline c punctiforme ATCC 29133-S & I fype UCD 153 & \\
\hline
\end{tabular}

\section{Cloning of NpDps and NpFdx genes in pSBA13 vector}

BioBrick plasmid pSB1A3 vector was (http://parts.igem.org/Part:pSB1A3) for heterologous expression of NpDps and NpFdx proteins. A Strep(II)-tag (W-S-H-P-Q-F-E K) was linked via a short 2-alanine linker (GCC GCA) to the 3' end of the targeted cloned gene, to which stop codon (TAA) was fused. The E. coli Dps protein-encoding gene, P0ABT2 (NC_000913.3), Npdps4 (Npun_R5799), Npdps5 (Npun_F6212) and the NpFdx protein-encoding genes, Npfdx1 (Npun_F3727), Npfdx9 (Npun_F4770) and NpfdxH (Npun_R0380) were amplified from isolated genomic DNA of E. coli or $N$. punctiforme, using Overlap Extension (OE) PCR [10]. The constructed vectors were transformed into E. coli DH5 $\alpha$ strain using chemical transformation method [22]. The resulting verified correct constructs were named as pVM27, pVM28, pVM29, pVM30, and pVM31 for expression of NpFdx1, NpFdx9, NpFdxH, NpDps4, and NpDps5 respectively (Table 1). Phusion DNA polymerase (Thermo Fisher Scientific) or PfuUltra II Fusion HS DNA Polymerase (Stratagene) were used as a polymerase in the OE PCR. Primers were designed using PrimerX software (http://bioinformatics.org/primerx/index.html) and are listed in Table 2.

Table 2. Plasmids and primers used in this work

\begin{tabular}{|c|c|c|}
\hline iids & ant properties & \\
\hline 13 & tagged, $A m p^{r}$ & s work \\
\hline 27 & 1 cloned into pSBA13, $\mathrm{Amp}^{\mathrm{r}}$ & s work \\
\hline 28 & 9 cloned into pSBA13, Amp ${ }^{\mathrm{r}}$ & p work \\
\hline 29 & $H$ cloned into pSBA13, Amp & \$ work \\
\hline$\beta 0$ & \$4 cloned into pSBA13, Ampr & s work \\
\hline$\beta 1$ & $\$ 5$ cloned into pSBA13, Amp ${ }^{r}$ & \$ work \\
\hline ers & \multicolumn{2}{|c|}{ er sequences $\left(5^{\prime}\right.$ to $\left.3^{\prime}\right)$} \\
\hline 1_For & \multicolumn{2}{|c|}{$\begin{array}{l}\text { CGAGAAAGAGGAGAAATACTAG } \\
\text {-CAACTTATAAAGTGACACTAATTAAC }\end{array}$} \\
\hline 1_Rev & \multicolumn{2}{|c|}{$\begin{array}{l}\text { TTTTCGAATTGGGGATGACTCCATGCGGC } \\
\text { sAGTTCTTCTTCTTTGTGA }\end{array}$} \\
\hline 9_For & \multicolumn{2}{|c|}{$\begin{array}{l}\text { CGAGAAAGAGGAGAAATACTAG } \\
\text { AAAAAACGAGTAACACTAACCTTC }\end{array}$} \\
\hline 9_Rev & \multicolumn{2}{|c|}{ TTTTCGAATTGGGGATGACTCCATGCGGC } \\
\hline
\end{tabular}




\begin{tabular}{|c|c|}
\hline \multirow{2}{*}{\begin{tabular}{|l|l|} 
KH_For \\
\end{tabular}} & GTTAGTGGAGATTGTA \\
\hline & CGAGAAAGAGGAGAAATACTAGATGG \\
\hline \multirow{2}{*}{ kH_Rev } & TTTTCGA \\
\hline & SCTACGAGATATGCTTCTTGATGTG \\
\hline 84_For & CGAGAAAGAGGAGAAATACTAGATGTCTGAAAGCGAAACTTTGTT, \\
\hline s4_Rev & TTTTCGAATTGGGGATGACTCCATGCGGCGCTTTGAGCCGCTTGGA \\
\hline 55_For & $\begin{array}{l}\text { CGAGAAAGAGGAGAAATACTAGATGCAAGAACTTGACTATAAAAA } \\
\text { ITC }\end{array}$ \\
\hline 55_Rev & TTTTCGAATTGGGGATGACTCCATGCGGCGCTAAAATCGCGTAGCA] \\
\hline For & CGAGAAAGAGGAGAAATACTAGATGAGTACCGCTAAATTAGTTAAA \\
\hline Rev & TTTTCGAATTGGGGATGACTCCATTCGATGTTAGACTCGATAAACCA \\
\hline A3_For & CGGCTGCGGCGAGCGG \\
\hline A3_Rev & $\begin{array}{l}\text { SCGGTTTGCGTATTGCTCTAGAAGCGG } \\
\text { EGAAT }\end{array}$ \\
\hline For & $\begin{array}{l}\text { ICTTCTAGAGCAATACGCAAACCGCCT } \\
\text { EC }\end{array}$ \\
\hline Rev & $\begin{array}{l}\text { iTATTTCTCCTCTTTCTCGAGTATGTGTGAA } \\
\text { ITATCCGCTCAC }\end{array}$ \\
\hline For & $\begin{array}{l}\text { STCATCCCCAATTCGAAAAATAACCAGGC } \\
\text { AATAAAACGAAAGGC }\end{array}$ \\
\hline $\operatorname{Rev}$ & DACTCAAAGGCGGTAAT \\
\hline
\end{tabular}

\section{Overexpression and purification of $N p D p s$ and $N p F d x$ proteins}

E. coli cells harboring pVM27, pVM28, pVM29, pVM30, and pVM31 were grown at $37{ }^{\circ} \mathrm{C}$ and $200 \mathrm{rpm}$ in $500 \mathrm{~mL} \mathrm{LB}$ medium containing $50 \mathrm{mg} \mathrm{mL}^{-1}$ ampicillin and additional $0.1 \mathrm{~g} \mathrm{~L}^{-1} \mathrm{FeCl}_{3}$ for the expression of $\mathrm{NpFdx} 1, \mathrm{NpFdx}$, NpFdxH, NpDps4, and NpDps5. At an $\mathrm{OD}_{600 \mathrm{~nm}}$ of 0.6, protein expression was induced by $1 \mathrm{mM}$ IPTG (isopropyl-beta-D-1-thiogalactopyranoside) for 5 - $6 \mathrm{~h}$. Cells were harvested and the cell pellet was suspended in $25 \mathrm{~mL}$ of lysis buffer containing $50 \mathrm{mM}$ Tris- $\mathrm{HCl}, \mathrm{pH} 8.0\left(4^{\circ} \mathrm{C}\right)$ and $1 \mathrm{M} \mathrm{NaCl}$. After the addition of $10 \mathrm{mg}$ lysozyme from chicken hen egg white (Sigma-Aldrich) and $3 \mathrm{mg}$ avidin (Sigma-Aldrich) the cells were disrupted by sonication. 10 $\mu \mathrm{L}$ Protease Arrest (G-Biosciences) was added and the lysate was incubated with 1 unit of DNase I (Thermo Scientific) for $40 \mathrm{~min}$ and then centrifuged at $10,000 \mathrm{x} \mathrm{g}$ for $30 \mathrm{~min}$ at $4{ }^{\circ} \mathrm{C}$. The resulted protein extract was stored overnight at $4{ }^{\circ} \mathrm{C}$ before purification. All proteins were purified by a 10 mL Strep-Tactin column (IBA) using an ÄKTA FPLC (GE Healthcare) equilibrated with degassed equilibration buffer containing $100 \mathrm{mM}$ Tris- $\mathrm{HCl} \mathrm{pH} 8.0,150 \mathrm{mM} \mathrm{NaCl}$ and $10 \mathrm{mM} \mathrm{MgCl}_{2}$ by following manufacturer's protocol (purification of Strep-tag fusion proteins with Strep-Tactin matrices from IBA Lifesciences). The protein extracts were centrifuged at $3500 \mathrm{x} g$ for $20 \mathrm{~min}$ at 4 ${ }^{\circ} \mathrm{C}$ before they were loaded onto the column. The elution of the Strep-tagged proteins was carried 
out in degassed equilibration buffer containing an additional 2.5 to $5 \mathrm{mM}$ d-desthiobiotin (SigmaAldrich). For NpFdx9 protein, we used degassed buffers and oxygen scavenging enzymes, $8 \mathrm{U} \mathrm{mL}^{-}$ 1 glucose oxidase (Sigma-Aldrich) and $100 \mathrm{U} \mathrm{mL}^{-1}$ catalase (Sigma-Aldrich), to have semianaerobic conditions during purification procedure. The eluted proteins were concentrated using 10 $\mathrm{kDa}$ centrifugal filter units (Merck). The buffer was changed to $50 \mathrm{mM} \mathrm{NaCl}$ and $10 \mathrm{mM}$ Tris- $\mathrm{HCl}$ pH 8.0 by using PD-10 columns (GE Healthcare). The protein concentration was determined using the DC protein assay (Bio-Rad) and the protein BSA (Sigma-Aldrich) served as a standard.

\section{Non-denaturing and denaturing gel electrophoresis}

Protein expression and purification were confirmed by Laemmli SDS-PAGE [33]. $0.8 \mu \mathrm{g}$ of each protein sample was applied onto Any kD gel (Bio-Rad). As a molecular mass marker, the SDSPAGE Broad Range Molecular mass standards (Bio-Rad) were used. Gel electrophoresis was performed at $200 \mathrm{~V}$, thereafter the gel was incubated overnight in colloidal Coomassie and subsequently de-stained in demineralized water [14]. Gel documentation was performed on a Chemi Doc XRS (Bio-Rad). The identity of each protein band was confirmed by mass spectrometry (see below). To investigate the multimeric forms of the purified Dps proteins $0.8 \mu \mathrm{g}$ of NpDps and EcDps and $1.5 \mu \mathrm{g}$ of BSA (Sigma) was mixed with loading buffer ( $25 \mathrm{mM} \mathrm{NaCl}, 30 \mathrm{mM}$ Tris-HCl pH 6.8 (RT), $20 \%$ glycerol and $0.005 \%$ (w/v) bromophenol blue) and applied to an Any kD gel (Bio-Rad). The separation buffer contained $25 \mathrm{mM}$ Tris- $\mathrm{HCl}$ and $192 \mathrm{mM}$ glycine $\left(\mathrm{pH} 8.0\right.$ at $\left.22^{\circ} \mathrm{C}\right)$. According to the manufacturer's guide, the gel possessed an intrinsic $\mathrm{pH}$ of 8.45 . The applied voltage was set to $100 \mathrm{~V}$ for the first $30 \mathrm{sec}$ and subsequently decreased to $40 \mathrm{~V}$ for $10 \mathrm{~h}$ at $22{ }^{\circ} \mathrm{C}$. The gel was stained and documented as described before for SDS-PAGE.

\section{Sample preparation and mass spectrometry analysis}

NpFdx, NpDps, and EcDps proteins were reduced, alkylated and in-gel digested by trypsin according to a standard operating procedure [55]. Thereafter the samples were dried and dissolved in $15 \mu \mathrm{L}$ of $0.1 \%$ formic acid. The peptides were separated in reversed-phase on a C18-column and electrosprayed on-line to Q Exactive Plus mass spectrometer (Thermo Finnigan). Tandem mass spectrometry was performed applying higher-energy C-trap dissociation. The data were analyzed by using the Sequest algorithm embedded in Proteome Discoverer 1.4 (Thermo Fisher Scientific) towards a FASTA database containing proteins from N. punctiforme ATCC 29133 and E. coli, downloaded from the SwissProt database. The search criteria for protein identification were set to at least two matching peptides of $95 \%$ confidence level per protein. Protein sequences for NpFdx 1 , NpFdx9, NpFdxH, NpDps4, and NpDps5 were received from the Cyanobase database 
(http://genome.microbedb.jp/cyanobase/) [26] for N. punctiforme and NCBI protein databases (https://www.ncbi.nlm.nih.gov/protein/) for E. coli. Protein sequences were aligned using Clustal Omega $[28,53]$.

\section{Electrophoretic mobility shift assay (EMSA)}

Prior to gel electrophoresis, $125 \mathrm{ng}$ of pSB1A3 plasmid DNA (2.5 kbp) was mixed with $1 \mu \mathrm{g}$ of each of the purified proteins at $\mathrm{pH} 6.0$ and $\mathrm{pH} 7.0$ in $5 \mu \mathrm{L}$ MES and Bis-Tris buffer systems $(50 \mathrm{mM}$ $\mathrm{NaCl}$ and $100 \mathrm{mM}$ buffer), respectively. Subsequently, after a $15 \mathrm{~min}$ incubation step at $22^{\circ} \mathrm{C}, 1 \mu \mathrm{L}$ of $6 \mathrm{x}$ loading buffer $(60 \%(\mathrm{v} / \mathrm{v})$ glycerol, $50 \mathrm{mM} \mathrm{NaCl}$ and $0.1 \%(\mathrm{w} / \mathrm{v})$ bromophenol blue) was added. The reaction volume was applied to a $1 \%(\mathrm{w} / \mathrm{v})$ agarose gel $(50 \mathrm{mM} \mathrm{NaCl}$ and $10 \mathrm{mM}$ of MES or Bis-Tris buffer). Gel electrophoresis was performed at a voltage of $30 \mathrm{~V}$ for $45 \mathrm{~min}$ at 22 ${ }^{\circ} \mathrm{C}$. The gels were stained in thiazole orange containing MES running buffer for $1 \mathrm{~h}$ under shaking in darkness. After two washing steps with demineralized water, documentation was performed on a Chemi Doc XRS (Bio-Rad). $1 \mu \mathrm{g}$ of E. coli Dps, EcDps, and $1 \mu \mathrm{g}$ bovine serum albumin (BSA) (Sigma) served as positive and negative controls respectively.

\section{Dynamic light scattering (DLS)}

Purified NpDps and EcDps proteins were diluted to a concentration between 70 to $100 \mu \mathrm{g} \mathrm{mL}^{-1}$ into $50 \mathrm{mM} \mathrm{NaCl}$ and $100 \mathrm{mM}$ buffer containing HEPES (pH 3.0), acetate (pH 5.0), succinate (pH 6.0), phosphate ( $\mathrm{pH}$ 7.0), Tris ( $\mathrm{pH} 8.0)$ and Bis-Tris propane ( $\mathrm{pH} 9.0)$. All buffer components were individually filtered ( $0.45 \mu \mathrm{m}$ Millipore filter HAWP-AO, Merck) before mixing. Prior to DLS analysis, all samples were centrifuged at $13,000 \mathrm{x}$ g for $5 \mathrm{~min}$ at $22^{\circ} \mathrm{C}$. DLS analysis was performed at $173^{\circ}$ (backscattering) on a Zetasizer Nano instrument (Malvern) using $1 \mathrm{~cm}$ path length polystyrene cuvettes (VWR). Experiments were performed at $25^{\circ} \mathrm{C}$. At each $\mathrm{pH}, 5$ to 13 data sets (each $100 \mathrm{sec}$ in duration) were collected for each protein. The hydrodynamic diameter of each protein species was calculated based on the mean from each dataset (number related size distribution). For background measurements, five datasets (each $100 \mathrm{sec}$ in duration) were collected for solutions at each $\mathrm{pH}$ without protein.

\section{UV-visible spectrophotometry and EPR spectroscopy of $\mathrm{NpFdx}$ proteins}

UV-visible spectra of $\mathrm{NpFdx} 1, \mathrm{NpFdxH}$, and $\mathrm{NpFdx} 9$ in their as-isolated state were measured either in $1 \mathrm{~mL}$ quartz cuvettes or in EPR quartz tubes $(0.3 \mathrm{~cm}$ path length) in a Varian Cary 50 Bio UV-visible spectrophotometer. Samples were diluted with $100 \mathrm{mM}$ Tris-HCl pH $8.0+150 \mathrm{mM}$ $\mathrm{NaCl}$ buffer when necessary so as to keep $\mathrm{Abs}<1$ for relevant features in the visible region of the spectra. For electron paramagnetic resonance (EPR) spectroscopy, 150 - $200 \mu \mathrm{L}$ of each sample in 
the as-isolated state was introduced in EPR quartz tubes suitable for X-band experiments. The tubes were then flushed with argon, capped with rubber septa, and frozen and kept in liquid nitrogen (77 $\mathrm{K})$ storage until measurement. Spectra were acquired at cryogenic temperatures ( $\mathrm{T}=7$ to $20 \mathrm{~K}$ ) using liquid helium as a coolant in a Bruker ELEXYS E500 spectrometer using an ER049X SuperX microwave bridge, and a Bruker SHQ4122 cavity, equipped with an Oxford Instruments continuous flow cryostat, and using an ITC 503 temperature controller (Oxford Instruments). To analyze the reduced state of iron-sulfur clusters in all ferredoxins, sodium dithionite (Sigma-Aldrich) was added to each EPR sample to a final concentration of $5 \mathrm{mM}$ (from a freshly-prepared anaerobic $100 \mathrm{mM}$ stock solution in $100 \mathrm{mM}$ Tris- $\mathrm{HCl} \mathrm{pH} 8.0+150 \mathrm{mM} \mathrm{NaCl}$ buffer). After incubation at room temperature $\left(20^{\circ} \mathrm{C}\right)$ for $30 \mathrm{~min}$, samples were re-frozen and new spectra were acquired. Spin quantification was performed based on the concentration of protein as calculated from UV-visible spectra, assuming $\varepsilon_{420}=9500 \mathrm{M}^{-1} \mathrm{~cm}^{-1}$ for both NpFdx1 $(100 \mu \mathrm{M})$ and $\mathrm{FdxH}(185 \mu \mathrm{M})$ and $\varepsilon_{420}=$ $15000 \mathrm{M}^{-1} \mathrm{~cm}^{-1}$ for $\mathrm{Fdx} 9(33 \mu \mathrm{M})$, and using $1 \mathrm{mM} \mathrm{CuSO}_{4}$ in $10 \mathrm{mM} \mathrm{HCl}$ as spin standard. Spectra acquisition and analyses were performed using the Xepr software package (Bruker).

\section{Protein labeling and sample preparation}

In Fluorescence correlation spectroscopy (FCS) experiments, lysines of NpDps and cysteines of $\mathrm{NpFdx}$ proteins were labeled with the fluorophore Atto550 ( $\lambda$ ex $544 \mathrm{~nm} ; \lambda \mathrm{em} 576 \mathrm{~nm})$ by following the protocol provided by the manufacturer (Atto-Tec) respectively. For DNA binding experiments, linear DNA was used in all experiments. In Fluorescence resonance energy transfer (FRET) experiments, lysines were labeled with donor Atto550 and cysteines were labeled with acceptor Atto647N ( $\lambda$ ex $644 \mathrm{~nm}$; $\lambda$ em $661 \mathrm{~nm}$ ) in NpDps and NpFdx proteins, respectively. In all cases, excess fluorophore was added to the aqueous protein solution and left for $8 \mathrm{~h}$ at $4{ }^{\circ} \mathrm{C}$. The labeled protein was subsequently purified using size exclusion chromatography on a Sephadex ${ }^{\mathrm{TM}}$ G-25 Medium column (GE Healthcare, UK). To remove excess free dyes from the labeled proteins and also avoid hydrolysis of an extra fluorophore, the samples were dialyzed ( $3 \mathrm{k}$ membrane) two times, $4 \mathrm{~h}$ of incubation in each time at $4{ }^{\circ} \mathrm{C}$. The freshly prepared complexes were immediately used for FCS and FRET experiments. For DNA and NpDps proteins interaction study, linear dsDNA $(\sim 0.25$ $\mathrm{kbp}, 500 \mathrm{nM}$ ) was incubated $30 \mathrm{~min}$ at $22{ }^{\circ} \mathrm{C}$ with $50 \mathrm{nM}$ of the each purified and labelled NpDps using $50 \mathrm{mM}$ Bis-Tris and HEPES buffer systems supplemented with $150 \mathrm{mM} \mathrm{NaCl}$ at $\mathrm{pH} 6.0$ and pH 8.0 respectively. In the case of FCS experiments considering NpFdxs interactions with NpDps, $100 \mathrm{nM}$ of each labeled NpFdxs were mixed with $500 \mathrm{nM}$ of each unlabeled $\mathrm{NpDps}$ for $2 \mathrm{~h}$ at $\mathrm{pH}$ 6.0 and 8.0. In the case of FRET experiments, $10 \mathrm{nM}$ of each labeled NpDps were mixed with $50 \mathrm{nM}$ of each labeled NpFdxs using 50 mM Bis-Tris buffer supplemented with $150 \mathrm{mM} \mathrm{NaCl}$ at pH 6.0. 
In all cases, we added $0.1 \%$ Tween-20 (Sigma) to the samples in order to diminish surface interactions with the glass coverslip.

\section{Fluorescence correlation spectroscopy}

FCS experiments were carried out with a custom-built confocal fluorescence microscope with a Zeiss C-Apochromat $40 \times 1.2 \mathrm{NA} \mathrm{H}_{2} \mathrm{O}$-immersion objective at $22^{\circ} \mathrm{C}$. The fluorescence intensity temporal fluctuations were analyzed with a hardware correlator (Flex02-12D/C correlator). All the experimental data were fitted in considering a single species and free Brownian 3D diffusion in the case of a Gaussian molecular detection efficiency.

$$
\tau)=1+\frac{1}{N}\left(1-\frac{B}{F}\right)^{2} \cdot\left(1+\mathrm{n}_{T} \cdot \exp \left(-\frac{\tau}{\tau_{T}}\right)\right) \cdot \frac{1}{\left(1+\frac{\tau}{\tau_{d}}\right) \sqrt{1+s^{2}\left(\frac{\tau}{\tau_{d}}\right)}}
$$

where $N$ is the average number of molecules in the focal volume, $F$ is the total fluorescence signal, $B$ is the background noise, $\mathrm{n}_{T}$ is the amplitude of the dark statepopulation, $\tau_{T}$ is the dark state blinking time, $\tau_{d}$ is the mean diffusion time and $S$ is the ratio of transversal to axial dimensions of the analysis volume. The molecular diffusion coefficient, $\mathrm{D}$ and hydrodynamic radius, $\mathrm{R}_{\mathrm{H}}$ were calculated as previously as described in detail [42]. The confocal volume was defined by using the $30 \mu \mathrm{m}$ confocal pinhole conjugated to the sample plane whose transversal waist $w_{x y}$ was calibrated to $285 \mathrm{~nm}$ using the known diffusion coefficient of Alexa 647 in pure water $\left(3.1 \times 10^{-6} \mathrm{~cm}^{2} \cdot \mathrm{s}^{-1}\right.$ at $22{ }^{\circ} \mathrm{C}$ ) and known hydrodynamic radius of $0.7 \mathrm{~nm}$ in pure water.

\section{Fluorescence resonance energy transfer (FRET)}

FRET detection was performed on a confocal inverted microscope with a Zeiss C-Apochromat 63 $\times 1.2 \mathrm{NA}$ water-immersion objective, and an iChrome-TVIS laser (Toptica $\mathrm{GmbH}$ ) as an exciting source operating at $550 \mathrm{~nm}$. The excitation power at the diffraction-limited spot was set to $20 \mu \mathrm{W}$ for all experimental conditions. Filtering the laser excitation was achieved by a set of two band-pass filters (Chroma ET525/70M and Semrock FF01-550/88). Dichroic mirrors (Chroma ZT594RDC and ZT633RDC) separate the donor and acceptor fluorescence light. The photodiode signal was recorded by a fast time-correlated single photon counting module (Hydraharp400, Picoquant $\mathrm{GmbH}$ ) in time-tagged time-resolved (TTTR) mode. The detection was performed by two avalanche photodiodes (Micro Photon Devices MPD-5CTC with $50 \mu \mathrm{m}$ active surface) with $620 \pm 20 \mathrm{~nm}$ (Chroma ET605/70M and ET632/60M) and 670 $\pm 20 \mathrm{~nm}$ (Semrock FF01-676/37) fluorescence 
band-pass filters for the donor and acceptor channels respectively. All fluorescence bursts above the background noise were recorded separately by the acceptor channel and donor channel. As a part of calibration, we took into consideration differences in the fluorescence detection efficiencies $\left(\eta_{A}\right.$ and $\left.\eta_{D}\right)$, direct excitation of the acceptor by the laser light $\left(n_{A}^{d e}\right)$, donor emission crosstalk into the acceptor channel $(\alpha)$ and quantum yields of fluorophores $\left(\varphi_{A}\right.$ and $\left.\varphi_{D}\right)$. Symphotime 64 (Picoquant $\mathrm{GmbH}$ ) software was used to compute the FRET efficiency according to the formula below:

$$
\mathrm{E}=\frac{n_{A}-\alpha n_{D}-n_{A}^{d e}}{n_{A}-\alpha n_{D}-n_{A}^{d e}+\gamma n_{D}}
$$

where $\gamma=\eta_{A} \varphi_{A} / \eta_{D} \varphi_{D}$ accounts for the differences in quantum yields $\left(\varphi_{A}\right.$ and $\left.\varphi_{D}\right)$ and fluorescence detection efficiencies $\left(\eta_{A}\right.$ and $\left.\eta_{D}\right)$ between the acceptor and donor.

We estimate $\gamma=1.3$, and $\alpha=0.16$ for the current setup. The Förster distance between the selected FRET pair is $62.6 \AA$.

\section{Results}

\section{Screening for ferredoxin candidates in Nostoc punctiforme}

To identify ferredoxin (NpFdxs) candidates to be used in the NpDps-Fdx interaction studies, we conducted in silico analyses of all annotated Fdxs in N. punctiforme (Table S1, Figs. S1 and S2). The Fdx, PaBfd from Pseudomonas aeruginosa (Figs. S1 and S2) was chosen as a template for the investigation, since this protein has shown to interact with a Bfr [24], and was also suggested to be involved in iron reduction and release from the Bfr. The phylogenetic study revealed one clade of [2Fe-2S]-cluster Fdxs, consisting of PaBfd and six NpFdxs, and one clade consisting of seven [4Fe4S]-cluster NpFdxs (Figs. S1 and S2). Among these, we proceeded with (i) NpFdx1, a homologue of a well-studied Fdx involved in photosynthesis in the cyanobacterium Synechocystis PCC 6803 [18], (ii) $\mathrm{NpFdxH}$, which homologue in Anabaena variabilis is heterocyst-specific [52], and (iii) NpFdx9 (Npun_F4770), which homologue in Synechocystis PCC 6803 is involved in oxidative and metal stress [18]. As the [Fe-S] cluster unit of the Fdx protein determines its cellular activities [11], we selected both $[2 \mathrm{Fe}-2 \mathrm{~S}]$ and $[4 \mathrm{Fe}-4 \mathrm{~S}]$ center-containing ferredoxins for the studies of interaction with NpDps4 and NpDps5.

\section{Purification and SDS-PAGE analysis of NpDps and NpFdx proteins}

All NpDps and NpFdx proteins, except $\mathrm{NpFdx}$, which contains the $\mathrm{O}_{2}$-sensitive [4Fe-4S] cluster, were purified using aerobic conditions. For $\mathrm{NpFdx} 9$ purification, we used partial anaerobic 
conditions, with de-gassed buffers, containing oxygen-scavenging enzymes. The purity of the proteins NpFdx1, NpFdx9, NpFdxH, NpDps4, and NpDps5, were analyzed by SDS-PAGE (Fig. 1). This analysis resulted in protein bands corresponding approximately to the theoretical sizes of the proteins including the attached Strep(II)- tag (Fig 1). Mass spectrometry (MS) analysis of NpFdx protein bands confirmed their identity as respective $\mathrm{NpFdx}$ protein. For NpDps proteins, a $22 \mathrm{kDa}$ protein size band was observed for NpDps4 (Fig. 1g) and two $20 \mathrm{kDa}$ bands for NpDps5 (Fig. 1h). All protein bands were analyzed and confirmed by MS. The origin of the double band pattern for NpDps5 is unknown. For EcDps, two strong protein size bands at $\sim 22 \mathrm{kDa}$ and a faint $37 \mathrm{kDa}$ protein size band were observed (Fig. 1i). MS analysis identified all three bands as EcDps sequences and a similar band pattern has been observed earlier in SDS-PAGE [51]. Schmidt [51] identified the double band pattern as the results of N-terminal digestion. The EcDps protein band of $37 \mathrm{kDa}$ might be a Dps-dimer as it was also identified by MS to be EcDps.
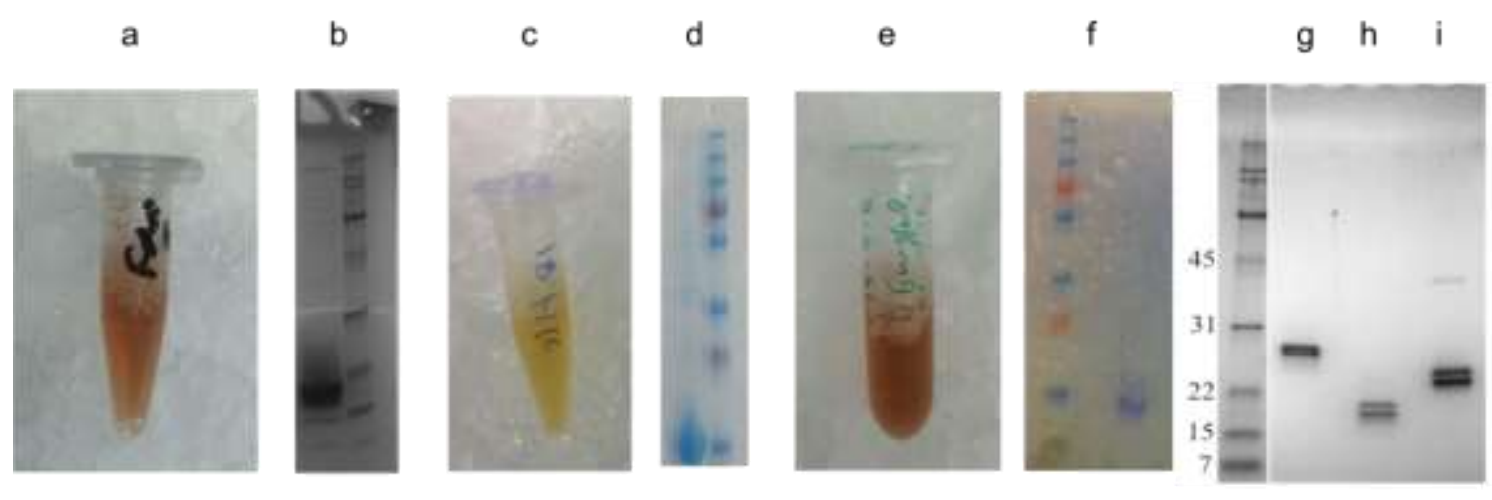

Figure 1. SDS-PAGE analysis of the recombinantly expressed and purified NpFdx, NpDps and EcDps. The calculated molecular mass of the proteins includes the added 2-alanine linker and Strep(II)-tag. The red colored ([2Fe-2S] cluster) $\mathrm{NpFdx} 1$ (a), and NpFdxH (e), and orange colored ([4Fe-4S] cluster) NpFdx9 (c) are shown. Panels b, $d$ and fare showing protein bands of $\mathrm{NpFdx} 1, \mathrm{NpFdx} 7$, and $\mathrm{NpFdx} 9$ with calculated molecular sizes of $11.8 \mathrm{kDa}, 12 \mathrm{kDa}$ and $15.8 \mathrm{kDa}$ respectively. Panels $\mathrm{g}, \mathrm{h}$ and $\mathrm{i}$ are showing protein bands of NpDps4, NpDps5 and EcDps with calculated molecular sizes of $22.0 \mathrm{kDa}, 17.7 \mathrm{kDa}$ and 19.9 kDa respectively. SDS-PAGE Broad Range Molecular weight standards (Bio-Rad) were used as molecular mass markers. Gels were stained with colloidal Coomassie dye. $1 \mu \mathrm{g}$ of each of the purified proteins was loaded on a SDS-PAGE gel. The identities of the protein within each protein band were confirmed by mass spectrometry.

\section{Spectroscopic characterization of $\mathrm{NpFdxs}$}

To ensure that the isolated $\mathrm{NpFdx}$ contained intact iron-sulfur clusters, and thus may act as electron donors to the NpDps, the number of iron and sulfur atoms of the iron-sulfur centers in the purified NpFdx samples were analyzed by UV-visible absorption spectroscopy in their as-isolated states.

Furthermore, due to the lack of biochemical data about the $\mathrm{NpFdx}$, this examination was also 
conducted to verify the annotations of Fe-S clusters for $\mathrm{NpFdx} 1, \mathrm{NpFdx}$, and $\mathrm{NpFdxH}$. Even though these $\mathrm{Fdxs}$ are annotated as $[2 \mathrm{Fe}-2 \mathrm{~S}]$ or $[4 \mathrm{Fe}-4 \mathrm{~S}]$ proteins, there have not been any experimental evidence established so far. This novel spectral information was crucial to proceed further with the biochemical and biophysical experiments. NpFdx1 exhibited well-defined absorption bands in the near-UV and visible regions with maxima at 277, 331, 421 and $464 \mathrm{~nm}$ (Fig. S6b, upper panel). NpFdxH showed a very similar spectrum, with maxima at 278, 334, 422 and 469 nm (Fig. S6b, middle panel). These spectral characteristics arise from ligand-to-metal charge transfer bands that are typical for [2Fe-2S] centers in the oxidized state [57]. In contrast, NpFdx9 presented broader absorption bands around the 320 and $420 \mathrm{~nm}$ region characteristic of proteins containing [3Fe-4S] and/or [4Fe-4S] centers (Fig. S6b, lower panel) [57]. In order to know the state of intact and functional features of [Fe-S] centers in the purified $\mathrm{NpFdx}$ proteins, EPR spectroscopy studies were conducted in their as-isolated, and chemically reduced states, using continuous wave $\mathrm{X}$-band electron paramagnetic resonance at cryogenic temperatures. In its as-isolated state, no resonances were visible for $\mathrm{NpFdx} 1$ (not shown) between $\mathrm{T}=11 \mathrm{~K}$ and $\mathrm{T}=20 \mathrm{~K}$; this result is consistent with the presence of [2Fe-2S] centers in the oxidized state. Upon one-electron reduction, a low-spin signal $(\mathrm{S}=1 / 2)$ was clearly detectable at $\mathrm{T}=15 \mathrm{~K}$ (Fig. S6a, upper panel). The spectrum presented a rhombic-shaped signal with field components at $g_{x}=1.90, g_{y}=1.97$ and $g_{z}=2.06$, and is characteristic for reduced [2Fe-2S] centers [58]. Spin quantification yielded $0.93 \mathrm{spin} / \mathrm{metal}$ center, very close to the expected $1 \mathrm{spin} /$ center. The same analysis was applied to $\mathrm{NpFdxH}$. In the as-isolated state, $\mathrm{NpFdxH}$ did not show any signals in EPR spectroscopy (not shown), but upon reduction, a low-spin signal $(\mathrm{S}=1 / 2)$, was clearly detectable at $\mathrm{T}=15 \mathrm{~K}$ (Fig. S6a, middle panel). The spectrum shows field components at $g_{x}=1.92, g_{y}=1.96$ and $g_{z}=2.05$; relaxation properties (not shown) are consistent with the presence of [2Fe-2S] centers. Spin quantification yielded 0.82 spin/metal center, which is slightly lower than NpFdx1; the difference might be due to incomplete reduction. In its as-isolated state. $\mathrm{NpFdx} 9$ exhibited a narrow signal centered at around $g=2.02$ at $\mathrm{T}=7 \mathrm{~K}$ (Fig. S6a, lower panel). Temperature and applied microwave power saturation behavior (not shown), as well as signal shape and field position, are characteristic of a low-spin, $\mathrm{S}=1 / 2$ [3Fe-4S] cluster in the oxidized state; [4Fe-4S] centers are EPR-silent $(\mathrm{S}=0)$ in the oxidized state [57]. Spectra acquired after reduction show the presence of mixed low-spin, $\mathrm{S}=1 / 2$ species at $\mathrm{T}=11 \mathrm{~K}$ characteristic of [4Fe-4S] centers (Fig. S6A, lower panel) [57]. The heterogeneity of the spectrum suggests the presence of mixed populations of protein presenting different spin distributions. Nevertheless, resonance shape and field positions, as well as temperature and applied microwave power saturation (not shown), indicate that the signals arise from magnetically uncoupled [4Fe-4S] centers. Spin quantification in $\mathrm{NpFdx} 9$ allowed us to estimate that most ( $0.80 \mathrm{spin} /$ metal center) of 
EPR-detectable iron-sulfur centers were [4Fe-4S] centers, with a minor population $(\sim 20 \%)$ being $[3 \mathrm{Fe}-4 \mathrm{~S}]$ centers. The presence of $[3 \mathrm{Fe}-4 \mathrm{~S}]$ centers is most likely due to the fact that the protein was purified in semi-anaerobic conditions, which can lead to the (reversible) loss of one iron.

\section{Multimerization properties of NpDps proteins}

The iron storage ability of Dps proteins is dependent on the oligomerization state of the protein complex. Therefore, we determined the state of the purified NpDps4 and NpDps5, under the different $\mathrm{pH}$ conditions that were used in the $\mathrm{NpDps-NpFdx} \mathrm{interaction} \mathrm{investigations.}$

To find the native multimeric sizes of the NpDps proteins, we used four different strategies (i) nondenaturing polyacrylamide gel electrophoresis (PAGE), (ii) size exclusion chromatography (iii) dynamic light scattering (DLS) and (iv) fluorescence correlation spectroscopy (FCS). Both NpDps4 and NpDps5 showed multimeric protein complexes when analyzed with non-denaturing PAGE at an approximate $\mathrm{pH}$ of 8.0 (Fig. 2a). Both NpDps4 and NpDps5 proteins formed large protein complexes, similar in sizes to the control protein EcDps that shows one clear band on the gel corresponding to the dodecameric form of the protein. NpDps5 also showed a band corresponding to a protein complex of lower mass. The approximate molecular masses of each NpDps protein were based on using the different multimeric forms of bovine serum albumin (BSA) as marker proteins [21], (Fig. 2a). To investigate the oligomeric forms and stability of NpDps4 and NpDps5, we performed DLS experiments under different $\mathrm{pH}$ conditions, ranging from $\mathrm{pH} 3.0$ to $\mathrm{pH} 9.0$ (Fig. 2b). EcDps served as a control protein to indicate the size of a Dps dodecamer, which has been earlier reported to be $\sim 101 \AA$ in hydrodynamic diameter by DLS analysis [25]. The monomeric form of EcDps derived from the crystal structure, possesses a cylindrical shape with its dimensions of about 17 × $60 \AA$ (radius x height) not including the random coil of the $\mathrm{N}$ - and C-termini (PDB:1DPS). At a $\mathrm{pH}$ range between 5 to 8, NpDps4, NpDps5 and EcDps formed protein species with an average hydrodynamic diameter larger than $99 \AA$ indicating the presence of multimeric protein complexes, presumably dodecamers. It should be noted that the standard error of the multimer of NpDps5 at pH 8.0 is comparatively large and may indicate a partial decomposition. At pH 3.0, NpDps5 was occasionally observed to form a protein species with a hydrodynamic diameter of $78 \AA$, indicating dissociation to a lower stable multimeric state, and at $\mathrm{pH} 9.0$ no protein species were found for any of the Dps, which may be due to complete protein denaturation. We also determined the overall oligomerization state of NpDps4 and NpDps5 in solution, by using size-exclusion chromatography, at pH 6.0 and 8.0. EcDps was used as a control. NpDps4 showed one well-defined oligomerization state at both pH 6.0 and pH 8.0. NpDps5 on the other hand showed 
one high multimeric conformation, but also one lower multimeric state at both pH 6.0 and 8.0 (Fig. $\mathrm{S} 3)$. The well-characterized E. coli Dps showed one high multimeric state at approximately the same retention time as the high multimeric states of both NpDps4 and NpDps5, thus indicating that all these Dps proteins are, in solution, at least partially, in a dodecameric form.

To explore the multimerization states of NpDps4 and NpDps5, the effect of global free diffusion of both NpDps proteins in aqueous solution were measured by FCS. Both NpDps4 and NpDps5 show the monophasic autocorrelation curves with diffusion times of $780 \pm 20 \mu \mathrm{s}\left(\mathrm{D}=2.11 \times 10^{-7} \mathrm{~cm}^{2} \cdot \mathrm{s}^{-1}\right)$ and $740 \pm 16 \mu \mathrm{s}\left(\mathrm{D}=2.24 \times 10^{-7} \mathrm{~cm}^{2} \cdot \mathrm{s}^{-1}\right)$ in aqueous solution at $\mathrm{pH} 6.0$, respectively (Fig. $3 \mathrm{c}$ and $3 \mathrm{~d}$, Table S2). The calculated hydrodynamic radii of the NpDps4 were $\approx 10.7 \mathrm{~nm}$ and $\approx 11 \mathrm{~nm}$ at pH 6.0 and pH 8.0 respectively (Fig. 3e). In sharp contrast, at pH 8.0, NpDps5 showed reduced diffusion times and decreased hydrodynamic radii around $\approx 5.61 \mathrm{~nm}\left(\mathrm{D}=4.04 \times 10^{-7} \mathrm{~cm}^{2} \cdot \mathrm{s}^{-1}\right)$ (Table S3) as compared to $10.1 \mathrm{~nm}\left(\mathrm{D}=2.24 \times 10^{-7} \mathrm{~cm}^{2} \cdot \mathrm{s}^{-1}\right)$ at $\mathrm{pH} 6.0$ (Fig. 3d and 3f, Table S2). In all the FCS experiments, we considered triplet state populations were less than $10 \%$.

a

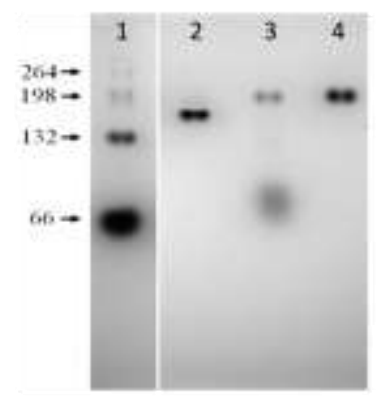

b

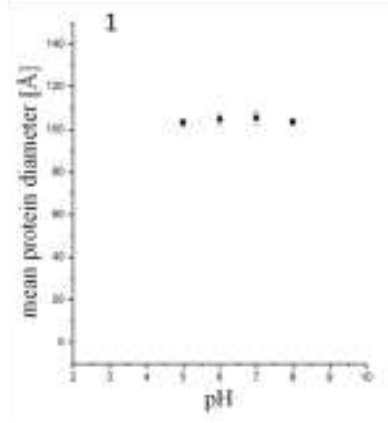

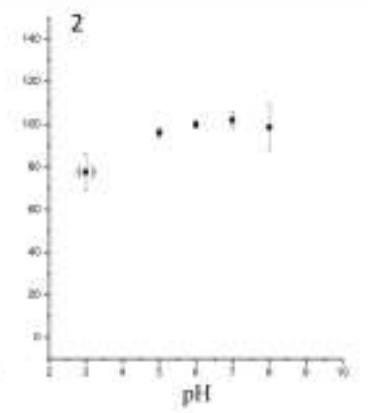

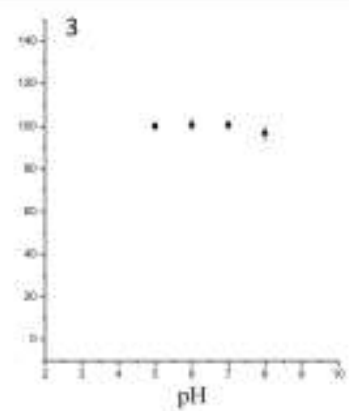

Figure 2. Multimeric size of the NpDps4, NpDps5, and EcDps analysed by non-denaturing PAGE and Dynamic light scattering (DLS). Non-denaturing PAGE (a) shows theoretical molecular masses of putative dodecamers were $262 \mathrm{kDa}$ for NpDps4 (a1), $210 \mathrm{kDa}$ for NpDps5 (a2), and $236 \mathrm{kDa}$ (a3) for EcDps. Additionally, the different native forms of bovine serum albumin (BSA) were used for estimating the approximate molecular masses. The pH of the gel was 8.45 and the $\mathrm{pH}$ of the running buffer was 8.0. Dynamic light scattering (b) shows the hydrodynamic diameters of NpDps4 (b1), NpDps5 (b2) and EcDps (b3) proteins at different $\mathrm{pH}$. All protein species are displayed as a mean of the average hydrodynamic diameter from each experimental series in $(\AA)$ at $\mathrm{pH}$ 3.0, 5.0, 6.0, 7.0 and 8.0. Particles with a lower peak occurrence than $1 \%$ (number related) are not shown, whereas particles with occurrence between $1 \%$ and $10 \%$ are shown in brackets. Standard error of the mean particle diameters is given as error bars.

\section{DNA binding properties of NpDps}

Dps are known to mechanically protect the genetic material of some bacteria against oxidative stress, in part due to the ability to bind to DNA [2]. To investigate the DNA binding properties of 
the two atypical NpDps, and to resolve if these were dependent on the $\mathrm{pH}$ and multimeric state of the NpDps, we conducted both in-solution as well as in-gel studies. In electrophoretic mobility shift assay (EMSA) both NpDps4 and NpDps5 formed dsDNA-Dps complexes at pH 6.0 as indicated by the DNA retardation in the gel (Fig. 3a). It is noticeable that NpDps4 shows weaker dsDNA-binding affinity than NpDps5 at pH 6.0 (Fig. 3a). At pH 7.0 the dsDNA-binding affinity for both NpDps was completely abolished (Fig. 3b). In neither $\mathrm{pH}$ condition the complete amount of the dsDNA was bound by the NpDps (unbound dsDNA was still observed) (Fig. 3a and 3b). We further studied the diffusion time of labeled NpDps upon interaction with dsDNA by using FCS, and the results showed that in solution both NpDps4 and NpDps5 show interaction with dsDNA at pH 6.0 (Fig.3c and 3d). In case of $\mathrm{NpDps} 4$, the diffusion times are longer, in the range of $960-1020 \mu \mathrm{s}(\mathrm{D}=1.71-1.62 \times$ $10^{-7} \mathrm{~cm}^{2} \cdot \mathrm{s}^{-1}$ ) in the presence of dsDNA molecules in comparison with the NpDps4 alone at both $\mathrm{pH}$ 6.0 and $\mathrm{pH} 8.0$ respectively (Fig. $3 \mathrm{c}$ ). The calculated hydrodynamic radii increased from $\approx 10.1 \mathrm{~nm}$ to $\approx 13.2 \mathrm{~nm}$ and $\approx 14.0 \mathrm{~nm}$ when the Npdps4 were incubated with dsDNA at both pH 6.0 and $\mathrm{pH}$ 8.0 (Fig. 3e). NpDps5 shows a similar increase in the calculated hydrodynamic radii from $\approx 10.1$ $\mathrm{nm}$ to $\approx 13.4 \mathrm{~nm}$ in the presence of dsDNA at pH 6.0 (Fig. 3f). On another hand, NpDps5 showed a similar range of diffusion times, and corresponding hydrodynamic radii ranges from $\approx 5.6 \mathrm{~nm}$ to $\approx$ $4.5 \mathrm{~nm}$ in the presence (respectively absence) of dsDNA at pH 8.0 (Fig. 3f). Thus, the FCS results clearly supported the in-gel (EMSA) results and showed that both NpDps4 and NpDps5 interact with DNA. 


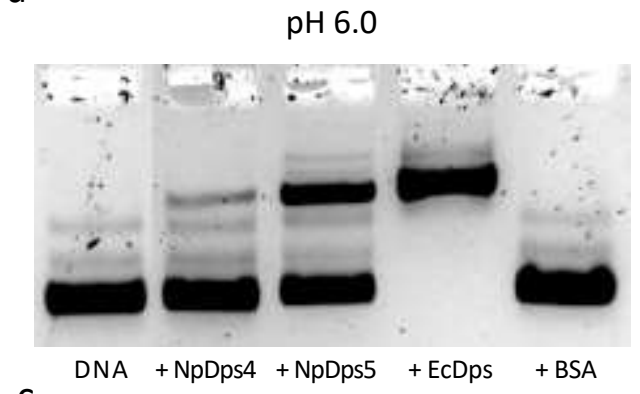

C
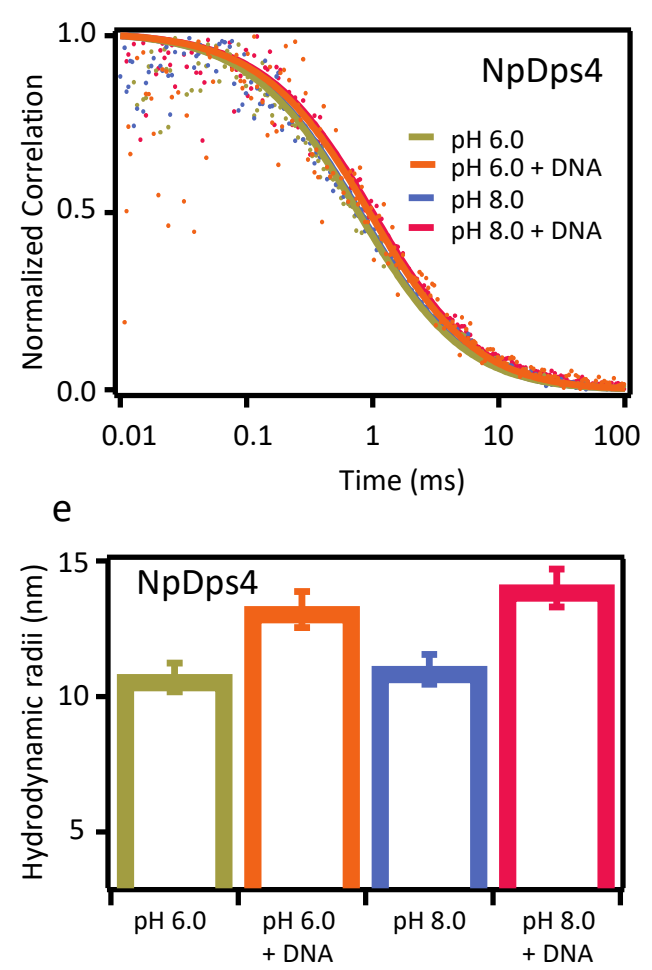

b
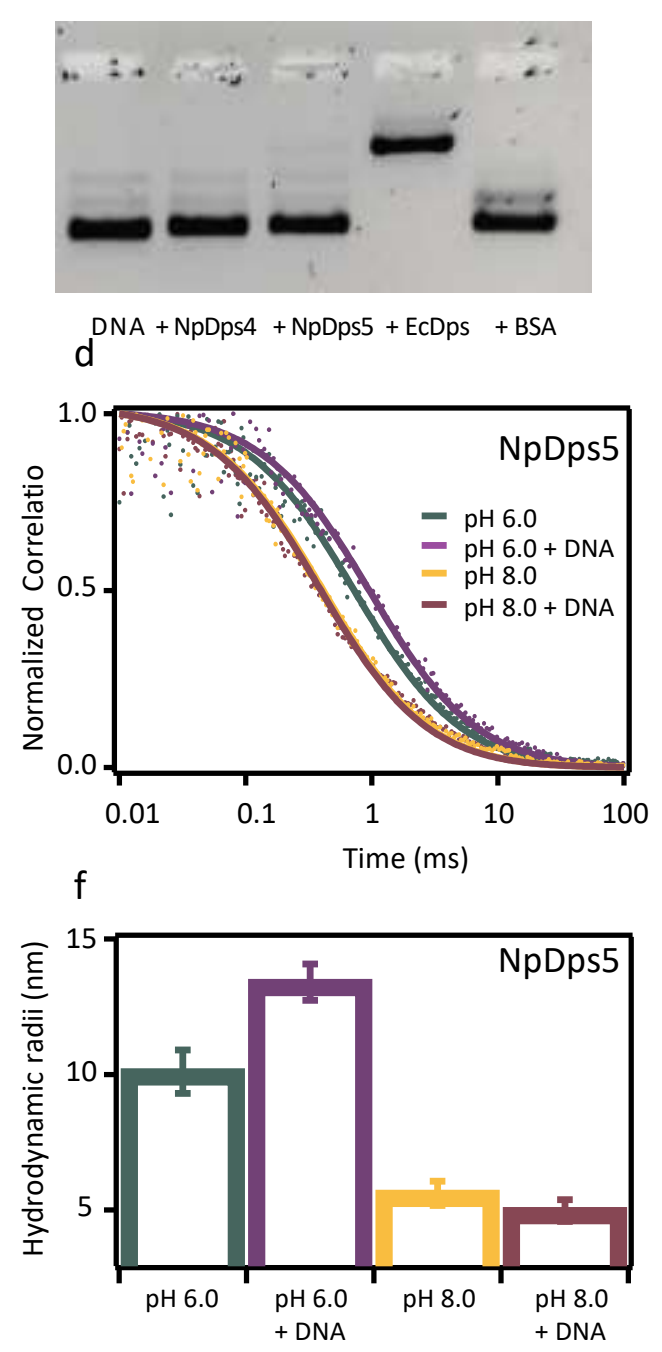

Figure 3. DNA binding properties of fluorescence labeled NpDps4, NpDps5 and unlabeled EcDps at different $\mathrm{pH}$ using EMSA and FCS methods. EMSA analysis of the DNA binding properties of the NpDps proteins at $\mathrm{pH} 6.0$ (a) and pH 7.0 (b). $125 \mathrm{ng}$ of plasmid DNA (pSB1A3 vector) was incubated with $1 \mu \mathrm{g}$ of NpDps protein material and separated on an agarose gel (1\%). EcDps and BSA served as positive and negative controls respectively. Plasmid DNA is shown in lane "DNA". Thiazole orange staining was performed after gel electrophoresis for DNA detection. Normalized FCS correlation traces of NpDps4 (c), NpDps5 (d) and corresponding apparent hydrodynamic radii (e \& f) obtained in the absence or presence of unlabeled dsDNA at $\mathrm{pH} 6.0$ and at $\mathrm{pH} 8.0$ in aqueous solution. Both NpDps4 and NpDps5 proteins show the monophasic autocorrelation curves.

\section{NpDps-NpFdx interactions}

To investigate the possible interactions between $\mathrm{NpDps}$ and $\mathrm{NpFdx}$ proteins, and how this interaction may change depending on $\mathrm{pH}$, FCS studies were conducted. To determine the hydrodynamic radii of $\mathrm{NpFdx} 1, \mathrm{NpFdx} 9$ and $\mathrm{NpFdxH}$, and how the corresponding hydrodynamic 
radii modulate upon interaction with $\mathrm{NpDps}$, we measured the diffusion times of labeled $\mathrm{NpFdx}$ with or without excessive amounts of NpDps4 or NpDps5 proteins. All free labeled NpFdx proteins show similar diffusion times of $300 \pm 20 \mu \mathrm{s}\left(\mathrm{D}=5.4 \times 10^{-7} \mathrm{~cm}^{2} \cdot \mathrm{s}^{-1}\right)$ at both $\mathrm{pH} 6.0$ (Fig. S4) and $\mathrm{pH} 8.0$ (data not shown). In the presence of $\mathrm{NpDps} 4$, all the $\mathrm{NpFdx}$ proteins showed increased diffusion time of $760 \pm 30 \mu \mathrm{s}\left(\mathrm{D}=2.1 \times 10^{-7} \mathrm{~cm}^{2} \cdot \mathrm{s}^{-1}\right)$, as compared to only the isolated $\mathrm{NpFdxs}$, at both pH 6.0 and 8.0 as exemplified for NpFdx1 (Fig. 4a). The calculated hydrodynamic radii result from the FCS data, summarizes that NpDps4 induce a similar noticeable change in hydrodynamic radii of $\mathrm{NpFdx} 1, \mathrm{NpFdx} 9$, and $\mathrm{NpFdxH}$ upon interactions at both pH 6.0 and 8.0 (Fig. 4c and S5). In the presence of $\mathrm{NpDps} 5, \mathrm{NpFdx} 1, \mathrm{NpFdx} 9$ and $\mathrm{NpFdxH}$ showed increased diffusion times of 810 $\pm 20 \mu \mathrm{s}\left(\mathrm{D}=2.0 \times 10^{-7} \mathrm{~cm}^{2} \cdot \mathrm{s}^{-1}\right), 780 \pm 20 \mu \mathrm{s}\left(\mathrm{D}=2.1 \times 10^{-7} \mathrm{~cm}^{2} \cdot \mathrm{s}^{-1}\right)$ and $660 \pm 20 \mu \mathrm{s}(\mathrm{D}=2.4 \times$ $10^{-7} \mathrm{~cm}^{2} \cdot \mathrm{s}^{-1}$ ) respectively, as compared to only the isolated NpFdxs (Fig. S5). The calculated hydrodynamic radii of NpDps5 in interaction with $\mathrm{NpFdx} 1, \mathrm{NpFdx} 9$ and $\mathrm{NpFdxH}$ were $11.1 \mathrm{~nm}$, $10.6 \mathrm{~nm}$, and $9.0 \mathrm{~nm}$ at pH 6.0 (Fig. 4c, Fig. S5, and Table S2). At pH 8.0, NpFdx1, NpFdx9, and $\mathrm{NpFdxH}$ in the presence of NpDps5 show diffusion times of $430 \pm 30 \mu \mathrm{s}\left(\mathrm{D}=3.8 \times 10^{-7} \mathrm{~cm}^{2} \cdot \mathrm{s}^{-1}\right)$, $450 \pm 20 \mu \mathrm{s}\left(\mathrm{D}=3.7 \times 10^{-7} \mathrm{~cm}^{2} \cdot \mathrm{s}^{-1}\right)$ and $309 \pm 10 \mu \mathrm{s}\left(\mathrm{D}=5.3 \times 10^{-7} \mathrm{~cm}^{2} \cdot \mathrm{s}^{-1}\right)(\mathrm{Fig}$. S5). The calculated hydrodynamic radii of NpDps5 in interaction with $\mathrm{NpFdx} 1, \mathrm{NpFdx} 9$ and $\mathrm{NpFdxH}$ at $\mathrm{pH}$ 8.0 were $5.8 \mathrm{~nm}, 6.1 \mathrm{~nm}$, and $4.2 \mathrm{~nm}$ respectively (Fig. 4c, Fig. S5, and Table S3) indicating weak interactions at $\mathrm{pH} 8.0$.

Based on the present data, we may conclude that under these experimental conditions both the NpDps4 and NpDps5 were multimers, putative dodecamers, at $\mathrm{pH}$ 6.0. At this $\mathrm{pH}$ similar hydrodynamic radii were identified for $\mathrm{NpFdx} 1$ and $\mathrm{NpFdx} 9$ upon interactions with both NpDps4 and NpDps5. These results were similar when the labeled NpFdx protein concentrations were kept at a constant concentration of $100 \mathrm{nM}$ and a high concentration of unlabelled NpDps $(2 \mu \mathrm{M})$ were added. Thus, the results indicate that even at high concentrations of proteins, it seems very likely, that the formed NpDps multimeric complexes stay in a stable soluble multimeric form in aqueous solution at $\mathrm{pH}$ 6.0. At more basic conditions NpDps5 does not occur to be a stable dodecamer, which is reflected in the determined lower hydrodynamic radii of all NpFdx upon interaction with NpDps5 at $\mathrm{pH} 8.0$ in comparison with at pH 6.0 (Fig. 4c and Fig. S5).

To determine possible interactions of NpFdxs and NpDps we used a confocal single molecule fluorescence resonance energy transfer strategy (FRET). By this method we determined if two fluorophores, in this case labeled NpFdxs and labeled NpDps are within a certain distance of each other. FRET histograms of the labeled NpFdxs in the presence or absence of labeled NpDps, at $\mathrm{pH}$ 6.0, are summarized in Figure 5. A pH of 6 was used to ensure the NpDps were in their multimeric 
states. For all of the only donor labeled NpFdxs that are freely diffusing in solution only one peak was observed in the energy transfer efficiency $(E)$ histograms, as exemplified for NpFdx1 (Fig. 5a). In the following description of the results, the normalized FRET values were interpreted, as a binding efficiency between NpDps and NpFdx proteins, would be visible as a change of FRET value. $\mathrm{NpFdx1-NpDps} 4$ interaction gave an maxima $E \sim 25 \%$ (Fig. 5a). NpFdxH-NpDps4 interaction shows a similar $E \sim 31 \%$ (Fig. 5c), while the NpFdx9-NpDps4 interaction shows a higher energy transfer efficiency maxima $E \sim 58 \%$ (Fig. 5b). Thus, indicating that the average distance between the labeled NpDps4 and labeled NpFdx9 are smaller as compared to the average distance between NpDps4 and NpFdx1 or NpFdxH. The interaction of NpDps5 as compared to the interaction of NpDps4 with the three $\mathrm{NpFdx}$ showed a different pattern of energy transfer efficiency maxima. The interaction of NpDps 5 with $\mathrm{NpFdx} 1$ and $\mathrm{NpFdx} 9$ gave similar $\mathrm{E}$ of $\sim 63 \%$ and $\sim 56$ $\%$, respectively (Fig. 5d and 5e), while the NpDps5-FdxH interaction shows a clear left-shifted peak at $\mathrm{E} \sim 15 \%$ (Fig. $5 \mathrm{f}$ ), which suggests that the average distance between NpDps5 and NpFdxH are longer as compared to the average distance between $\mathrm{NpFdx} 1 / \mathrm{NpFdx} 9$ and NpDps5.
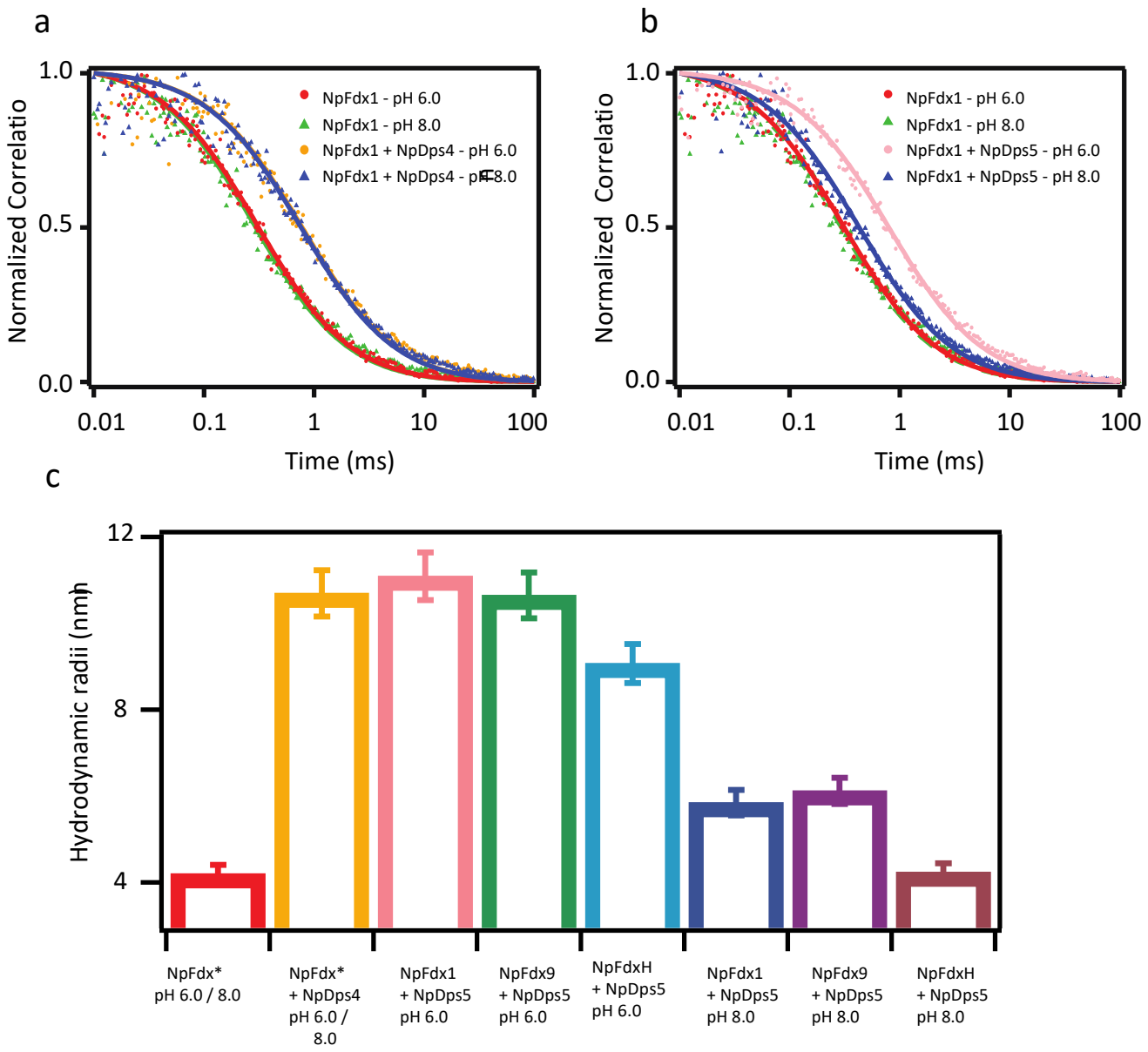
Figure 4. FCS data on the labeled NpFdxs in concern together with excess amounts of NpDps4 and NpDps5 in aqueous solution. Normalized FCS correlation traces of NpFdx1 in the presence of NpDps4 (a) and in the presence of NpDps5 (b) at pH 6.0 and 8.0 in aqueous solution. Deduced hydrodynamic radii obtained for ferredoxin proteins $(\mathrm{NpFdx} *)$ in the absence or presence of NpDps4 and NpDps5 at pH 6.0 and 8.0 (c). Here, NpFdx* represents NpFdx1 / NpFdx9 / $\mathrm{NpFdxH}$. For details see supporting figure 5.
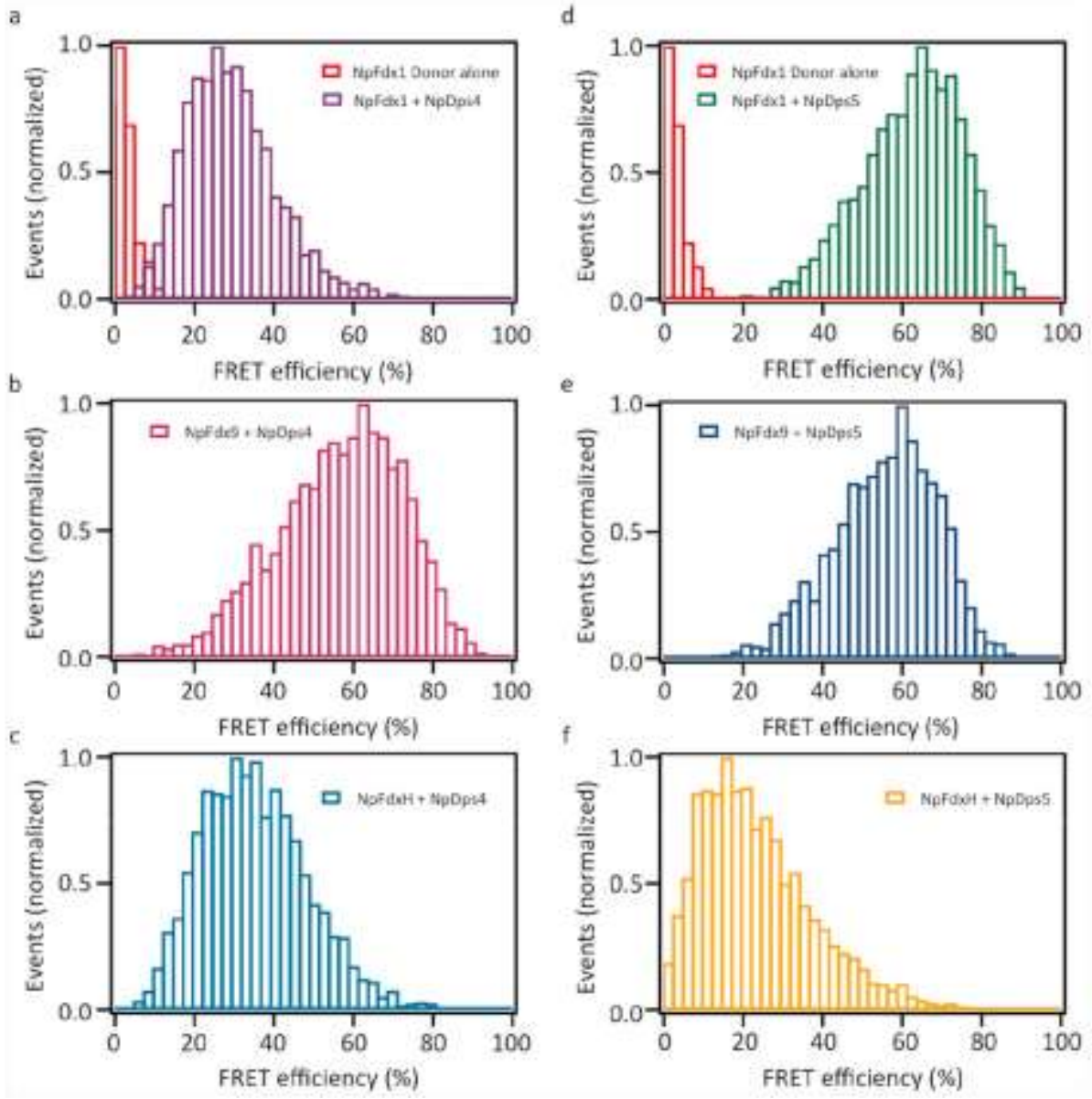

Figure 5. Inter-FRET efficiency histograms of $\mathrm{NpFdx}$ variants and NpDps variants. The higher value in FRET histogram indicates the higher degree of compactness between proteins. Intermolecular FRET of NpFdx1-NpDps4 complex (a), NpFdx9-NpDps4 complex (b), NpFdxH-NpDps4 complex (c), NpFdx1-NpDps5 complex (d), NpFdx9NpDps5 complex (e), and NpFdxH-NpDps4 complex (f) in comparison with NpFdx1 donor alone. In FRET histograms corresponding $\mathrm{NpFdx}$ proteins labeled with only donor fluorophore was used as a reference. Gaussian distributions were used to fit the data (data not shown). All experiments were carried out at $21^{\circ} \mathrm{C}$ at $\mathrm{pH} 6.0$.

\section{Discussion}


Here we continue our exploration of ferritin-like proteins in N. punctiforme, which is a bacterium equipped with an unusually complex set of five Dps proteins (NpDps1 - 5). In our earlier studies, NpDps1 - 3 were shown to cluster together with Dps proteins, such as the Dps family prototype of Escherichia coli, and thus classified as canonical Dps proteins. On the other hand, NpDps4 were clustered with atypical Dps, and NpDps5 with Bfrs, and were therefore classified as non-canonical Dps proteins [31, 23]. Our working hypothesis is that each NpDps protein has a specific physiological role, and insights into their biochemical properties will help to understand the multilayered network of iron homeostasis and oxidative stress tolerance in N. punctiforme. In this study we hypothesized that NpFdx interact with the two atypical Dps proteins in N. punctiforme, and therefore may mediate electron transfer for reduction and release of the stored iron.

We also aimed at describing NpDps4 and NpDps5 in terms of their protein multimerization, $\mathrm{pH}$ stability and their possible interaction with ferredoxins and DNA. Indeed, the results obtained from the interaction studies of NpDps and NpFdxs show for the first time that Dps proteins can interact with Fdxs. Although the physiological relevance of the NpDps-NpFdx interaction is hard to predict, our results show that the interactions are dependent on $\mathrm{pH}$, state of multimerization of the Dps and on the specific NpDps-NpFdx pair.

\section{NpDps4 and NpDps5 form dodecameric structures}

For the Dps to be able to store iron within the cell it needs to be in its multimeric form under physiological conditions. Certainly, both NpDps4 and NpDps5 form high states of multimeric complexes, presumably dodecamers under physiological $\mathrm{pH}$. Of the two, NpDps4 was found to be more stable within a wider range of $\mathrm{pH}$ conditions. The level of multimerization was similar for the two NpDps which suggest that even if NpDps5 is structural similar to a Bfr [23] it forms a dodecameric protein as for typical Dps, and not a 24-meric protein complex as for typical Bfr.

DLS results showed that NpDps4 and NpDps5 have individual optimal pH ranges for stability and multimerization in solution. Both $\mathrm{NpDps}$ form high molecular complexes between $\mathrm{pH}$ 5.0 to 8.0, whereas at $\mathrm{pH} 3.0$ and $\mathrm{pH} 9.0$ they are likely completely denatured (Fig. 2b). Size exclusion chromatography (Fig. S3) as well as FCS results supported these observations and confirmed that NpDps4 and EcDps were stable in their multimeric states at pH 6.0 and at pH 8.0, while NpDps5 appeared in higher and lower multimeric states at $\mathrm{pH} 6.0$ and at $\mathrm{pH} 8.0$ respectively. The dissociation at alkaline conditions does not seem to be due to total degradation, since predominant multimeric states were identified for both NpDps with all these complementary methods for determination of size. Therefore, we suggest that the dissociation of the multimeric form is $\mathrm{pH}$-dependent. In general, the dodecameric shape of Dps proteins has been shown to be important for DNA binding, iron 
incorporation, and circumventing the Fenton reaction [16]. The realization of the individual $\mathrm{pH}$ dependences of the dodecameric structures was used to design the interactions studies and to interpret the results of these studies.

\section{NpDps4 and NpDps5 show interaction with DNA}

We found that both NpDps4 and NpDps5 interact with DNA in a pH dependent fashion. Actually, this was a surprising result since NpDps5 is structurally similar to Bfr [23] a group of ferritin-like proteins which is not known to bind DNA.

Both NpDps4 and NpDps5 interacted with DNA at pH 6.0 in the gel-based EMSA experiments, but did not show binding at $\mathrm{pH}$ 7.0. In contrast the FCS data show NpDps specific $\mathrm{pH}$ dependent DNA binding. NpDps4 interacts with DNA at both pH 6.0 and at pH 8.0 while NpDps5 only show complex formation at $\mathrm{pH}$ 6.0. It may be that the electrostatic interaction, which is the common basis for DNA and Dps interaction [15], is impeded by the external electrical field that is applied during EMSA, a method that has to be regarded as more invasive as compared to FCS. The pattern for NpDps5-DNA interaction seen in the FCS experiments correlates with the loss of dodecameric structure of $\mathrm{NpDps} 5$ at $\mathrm{pH} 8.0$ indicating the importance of the dodecamer structure for DNAbinding, at least in vitro.

The general mechanism of DNA binding by Dps proteins was provided for E. coli Dps, which carries three lysine residues at its $\mathrm{N}$-terminus, that can be positively charged under physiological $\mathrm{pH}$, and there upon forms large Dps-DNA complexes in vitro [15]. NpDps4 and NpDps5 exhibit a weaker DNA binding affinity as compared to the control EcDps (Fig. 3a, b). The poor NpDps4-DNA interaction is not easily explained by electrostatic properties, but the low number of positively charged amino acids in its terminal tail may be of significance (one arginine in the $\mathrm{N}$-, one lysine at the C-terminus). Since both $\mathrm{N}$ - and C-termini are naturally short in NpDps5, the protein surface charges might be more relevant for NpDps5-DNA complex formation, as proposed for the Dps from Helicobacter pylori [17]. This biochemical property is dependent on $\mathrm{pH}$ that will modulate the overall protonation of the protein, which could lead to gain or loss of interaction [16]. While our study does not focus on this hypothesis, it is nevertheless an interesting avenue to pursue in a future study.

The long-standing hypothesis that DNA-binding would physically protect DNA from hydroxyl radicals $(\mathrm{OH})$, a ROS that is produced by the Fenton reaction, appears to be rather indefensible since many Dps proteins have been identified to protect DNA from this reaction without the capability to interact with DNA [6]. Therefore, it is likely that DNA binding fulfils other physiological roles such as DNA compaction [20] or physical protection from higher temperatures 
[19]. Dynamic state of DNA topology is essential for genome condensation in bacteria and has been studied in vitro for the gram-negative prokaryote E. coli [15] and the gram-positive Staphylococcus aureus [43]. As N. punctiforme in total contains five different Dps proteins, of which NpDps2, NpDps3 [31], NpDps4 and NpDps5 can form DNA-Dps complexes, it remains to be shown if any of these DNA-binding capabilities are of physiological relevance.

\section{NpFdx proteins are possible electron donors for NpDps}

$\mathrm{NpFdx}$ proteins interact with NpDps4 and NpDps5, suggesting a potential role of these electron transfer proteins in redox activities of $\mathrm{NpDps}$. Homologues of $\mathrm{NpFdx} 1, \mathrm{NpFdx} 9$ and $\mathrm{NpFdxH}$ act as electron donors or are involved in various metabolic reactions in microalgae [30, 3, 18]. A homologue of $\mathrm{NpFdx} 1$ in Chlamydomonas reinhardtii, the photosynthetic ferredoxin, PetF acts as an electron carrier and plays a crucial role in the efficient electron transfer between Photosystem I (PSI) and the [FeFe] hydrogenase HydA1 [61, 62]. FdxH is a heterocyst localized protein and has been shown to function as an electron donor to nitrogenase [9]. FdxH takes electrons from PSI in the light but can also be reduced by ferredoxin:NADPH oxidoreductase in darkness with the NADPH produced in oxidative pentose phosphate pathway [7]. All these electron transfer reactions are essentially based on the interaction of $[\mathrm{Fe}-\mathrm{S}]$ clusters from the donor (ferredoxin) to the acceptor protein (nitrogenase, PS I, hydrogenase). The [Fe-S] centers of the NpFdx1, NpFdx9 and NpFdxH from $N$. punctiforme were experimentally characterized and found to be consistent with those predicted from their primary protein structures, namely, $\mathrm{NpFdx} 1$ and $\mathrm{NpFdxH}$ containing [2Fe-2S] and NpFdx9 [4Fe-4S] centers. Previous studies have shown that Fdxs are able to reduce the iron core of Bfr [4], and thus release iron under in vitro conditions. In this study we have shown that indeed NpFdx1, NpFdx9 and NpFdxH do interact with NpDps4 and NpDps5 under some of the tested conditions, and the characteristics of the protein interactions are dependent on the Fdx-Dps couple. Based on the present inter-FRET efficiencies one can calculate the distance between the fluorophores between NpFdx and NpDps proteins. NpFdx 1 and NpFdxH are more than $70 \AA$ from NpDps4 (Fig. 5) In NpFdx9-NpDps4 complex, this distance is $\sim 61 \AA$ (Fig. 5). In formed complexes NpDps5-NpFdx1, NpDps5-NpFdx9 and NpDps5-FdxH, NpFdx proteins show different distances in a range $\sim 61 \AA$ to $85 \AA$ to NpDps5. Considering all, one may speculate that each NpFdx and NpDps proteins show unique binding induced modulation upon interaction with each other, which reflects the energy efficiency between the $\mathrm{NpFdx}$ donor and $\mathrm{NpDps}$ acceptor molecules.

The interaction studies support our hypothesis that $\mathrm{NpFdx}$ proteins are involved in iron regulation, probably by reduction of stored iron that could be released to re-enter the metabolism. It should be noted that Bfrs contain a heme group on the 2 -fold symmetry axis between two subunits thus 
electronically connecting the protein exterior with the inner oxidized iron core. On the contrary the Dps proteins don't contain heme and the routes of electron transfer remain unknown. These electron transfer routes are of crucial importance to understand the role of Dps in cellular iron homeostasis in general, and more specifically for heterocyst metabolism.

\section{Acknowledgements}

This work was supported by NordForsk NCoE program "NordAqua" (project \# 82845), and the Swedish Energy Agency (project \# 11674-5) (KS). Funding from Carl Tryggers foundation (KS) and Sven and Lilly Lawski foundation (VKM) are also acknowledged. The research leading to these results has also received funding from the European Research Council (ERC) under the European Union's Seventh Framework Programme (FP7/2007-2013) / ERC Grant agreement 278242 (ExtendFRET) and the European Union's Horizon 2020 research and innovation programme (grant agreement No 723241 TryptoBoost).

\section{References}

[1] P. Aisen, C. Enns, M. Wessling-Resnick, Chemistry and biology of eukaryotic iron metabolism, Int. J. Biochem. Cell. Biol. 33 (2001) 940-959.

[2] M. Almiron, A.J. Link, D. Furlong, R. Kolter, A novel DNA-binding protein with regulatory and protective roles in starved Escherichia coli, Genes Dev. Vol 6 (1992) 2646-54.

[3] Y. Allahverdiyeva, M. Ermakova, M. Eisenhut, P. Zhang, P. Richaud, M. Hagemann, L. Cournac, E.M Aro, Interplay between flavodiiron proteins and photorespiration in Synechocystis sp. PCC 6803, J. Biol. Chem. 286 (2011) 24007-24014.

[4] S.C. Andrews, A.K. Robinson, F. Rodriguez-Quinones, Bacterial iron homeostasis. FEMS. Microbiol. Rev. 27 (2003) 215-237.

[5] B. Bergman, J.R. Gallon, A.N. Rai, L.J. Stal, N2 Fixation by non-heterocystous cyanobacteria, FEMS Micro. Rev. 19 (1997) 139-185.

[6] G. Bellapadrona, M. Ardini, P. Ceci, S. Stefanini, E. Chiancone, Dps proteins prevent Fentonmediated oxidative damage by trapping hydroxyl radicals within the protein shell, Free Radic Biol Med. 48 (2010) 292-297.

[7] H. Bothe, O.M. Schmitz, M.G. Yates, E. William, 2010, Nitrogen Fixation and Hydrogen Metabolism in Cyanobacteria, Micro. Mol. Biol. Rev. 74 (2010) 529-551.

[8] H. Böhme, B. Schrautemeier, Comparative characterization of ferredoxins from heterocysts and vegetative cells of Anabaena variabilis, Biochim. Biophys. Acta. 891 (1987) 1-7. 
[9] H. Böhme, R. Haselkorn, Molecular cloning and nucleotide sequence analysis of the gene coding for heterocyst ferredoxin from the cyanobacterium Anabaena sp. strain PCC 7120, Mol. Gen. Genet. 214 (1988) 278-285.

[10] A.V. Bryksin, I. Matsumura, Overlap extension PCR cloning: a simple and reliable way to create recombinant plasmids, BioTechniques. 48 (2010) 463-465.

[11] K. Brzoska, S. Meczynska, M. Kruszewski, Iron-sulfur cluster proteins:electron transfer and beyond, Acta. Biochimica. Polonica. 53 (2006) 685-691.

[12] M. Castruita, M. Saito, P.C. Schottel, L.A. Elmegreen, S. Myneni, E.I. Stiefel, F.M.M. Morel, Overexpression and characterization of an iron storage and DNA-binding Dps protein from Trichodesmium erythraeum, Appl. Environ. Microbiol. 72 (2006) 2918-2924.

[13] E.L. Campbell, H. Christman, J.C. Meeks, DNA Microarray Comparisons of Plant Factor- and Nitrogen Deprivation-Induced Hormogonia Reveal Decision-Making Transcriptional Regulation Patterns in Nostoc punctiforme, J. Bacteriol. 190 (2008) 7382-7391.

[14] G. Candiano, M. Bruschi, L. Musante, L. Santucci, G.M. Ghiggeri, B. Carnemolla, P. Orecchia, L. Zardi, P.G. Righetti, Blue silver: a very sensitive colloidal Coomassie G-250 staining for proteome analysis, Electrophoresis. 25 (2004) 1327-1333.

[15] P. Ceci, S. Cellai, E. Falvo, C. Rivetti, G. Rossi, E. Chiancone, DNA condensation and selfaggregation of Escherichia coli Dps are coupled phenomena related to the properties of the Nterminus, Nucleic. Acids. Res. 32 (2004) 5935-5944.

[16] P. Ceci, A. Ilari, E. Falvo, L. Giangiacomo, E. Chiancone, Reassessment of protein stability, DNA binding, and protection of Mycobacterium smegmatis Dps, J. Biol. Chem. 280, (2005) 3477634785.

[17] P. Ceci, L. Mangiarotti, C. Rivetti, E. Chiancone E, The neutrophil-activating Dps protein of Helicobacter pylori, HP-NAP, adopts a mechanism different from Escherichia coli Dps to bind and condense DNA, Nucleic. Acids. Res. 35 (2007) 2247-2256.

[18] C.C. Chauvat, F. Chauvat, Function and Regulation of Ferredoxins in the Cyanobacterium Synechocystis PCC6803: Recent Advances, Life. 4 (2014) 666-680.

[19] E. Chiancone, Dps Proteins, an Efficient Detoxification and DNA Protection Machinery in the Bacterial Response to Oxidative Stress. Rend. Fis. Acc. Lincei 19 (2008) 261-270.

[20] E. Chiancone, P. Ceci, The multifaceted capacity of Dps proteins to combat bacterial stress conditions: detoxification of iron and hydrogen peroxide and DNA binding, Biochim. Biophys. Acta. 1800 (2010) 798-805.

[21] R.P. Chowdhury, M. Vijayabaskar, S. Vishveshwara, D. Chatterji, Molecular mechanism of in vitro oligomerization of Dps from Mycobacterium smegmatis: Mutations of the residues identified by "Interface Cluster" analysis, Biochemistry. 47 (2008) 11110-11117. 
[22] S.W. Edward, Chemical Transformation of E.coli. E.coli Plasmid Vectors, Methods. Mol. Biol. 235 (2003) 49-53.

[23] M. Ekman M, G. Sandh, A. Nenninger, P. Oliveira, K. Stensjö, Cellular and functional specificity among ferritin-like proteins in the multicellular cyanobacterium Nostoc punctiforme. Environ. Microbiol. 16 (2014) 829-844.

[24] K. Eshelman, H. Yao, A.N.D. Punchi Hewage, J.J. Deay, J.R. Chandler, M. Rivera, Inhibiting the BfrB:Bfd interaction in Pseudomonas aeruginosa causes irreversible iron accumulation in bacterioferritin and iron deficiency in the bacterial cytosol. Metallomics. 9 (2017) 646-659.

[25] R. Fan, A.L. Boyle, V.V. Cheong, S.L. Ng, B.P. Orner, A helix swapping study of two protein cages. Biochemistry. 48 (2009) 5623-5630.

[26] T. Fujisawa, R. Narikawa, S. Maeda, S. Watanabe, Y. Kanesaki, K. Kobayashi, J. Nomata, M. Hanaoka, M. Watanabe, S. Ehira, CyanoBase: a large-scale update on its 20th anniversary, Nucleic. Acids. Res. 45 (2016) 551-554.

[27] A. Grove, S.P. Wilkinson, Differential DNA binding and protection by dimeric and dodecameric forms of the ferritin homolog Dps from Deinococcus radiodurans, J. Mol. Biol. 347 (2005) 495-508.

[28] M. Goujon M, H. McWilliam H, W. Li, F. Valentin, S. Squizzato, J. Paern, R. Lopez, A new bioinformatics analysis tools framework at EMBL-EBI. Nucleic. Acids. Res. 38 (2010) 695-699.

[29] T. Haikarainen, A.C. Papageorgiou, Dps-like proteins: structural and functional insights into a versatile protein family, Cell. Mol. Life Sci. 67 (2010) 341-351.

[30] G. Hanke, P. Mulo, Plant type ferredoxins and ferredoxin-dependent metabolism, Plant. Cell. Environ. 36 (2013) 1071-1084.

[31] C. Howe, F. Ho, A. Nenninger, P. Raleiras, K. Stensjö, Differential biochemical properties of three canonical Dps proteins from the cyanobacterium Nostoc punctiforme suggest distinct cellular functions, J. Biol. Chem. 293 (2018), 16635-16646.

[32] A. Ilari, S. Stefanini, E. Chiancone, D. Tsernoglou, The dodecameric ferritin from Listeria innocua contains a novel inter subunit iron-binding site, Nat. Struct. Biol. 7 (2000) 38-43.

[33] U,K. Laemmli, Cleavage of structural proteins during the assembly of the head of bacteriophage T4, Nature. 227 (1970) 680-685.

[34] A. Latifi, M. Ruiz, C.C. Zhang, Oxidative stress in cyanobacteria. FEMS Microbiol. Rev. 33 (2009) 258-278.

[35] N.E. Le Brun, A. Lewin, G.R. Moore, Formation of protein-coated iron minerals. Dalton Transactions. 22 (2005) 3597-3610.

[36] S.J. Lippard, J.M. Berg, Principles of bioinorganic chemistry. Herndon, VA: University Science Books, 1994. 
[37] X. Li, H. Mustila, A. Magnuson, K. Stensjo, Homologous overexpression of NpDps2 and NpDps5 increases the tolerance of oxidative stress in the multicellular cyanobacterium Nostoc punctiforme, FEMS Microbiol. Lett. 365 (2018) 1-8.

[38] A. Martinez, R. Kolter, Protection of DNA during oxidative stress by the nonspecific DNAbinding protein Dps, J. Bacteriol. 179 (1997) 5188-5194.

[39] J.C. Meeks, J. Elhai, T. Thiel, M. Potts, F. Larimer, J. Lamerdin, P. Predki, R. Atlas, An overview of the genome of Nostoc punctiforme, a multicellular, symbiotic cyanobcaterium. Photosynth. Res, 70 (2001) 85-106.

[40] B. Miroux, J.E. Walker, Over-production of proteins in Escherichia coli: mutant hosts that allow synthesis of some membrane proteins and globular proteins at high levels, J. Mol. Biol. 260 (1996) 289-298.

[41] V.K. Moparthi, X. Li, K. Vavitsas, I. Dzhygyr, G. Sandh, K. Stensjö, The two Dps proteins, Npun_F3730 and Npun_F6212, are involved in light-induced oxidative stress tolerance in the $\mathrm{N}_{2}$ fixing cyanobacterium, Nostoc punctiforme. Biochim. Biophys. Acta. Bioenergetics, 1857 (2016) 1766-1776.

[42] S.B. Moparthi, G. Thieulin-Pardo, P. Mansuelle, H. Rigneault, B. Gontero, J. Wenger, Conformational modulation and hydrodynamic radii of CP12 protein and its complexes probed by fluorescence correlation spectroscopy, FEBS. J. 281 (2014) 3206-3217.

[43] K. Morikawa, R.L. Ohniwa, J. Kim, A. Maruyama, T. Ohta, K. Takeyasu, Bacterial nucleoid dynamics: oxidative stress response in Staphylococcus aureus, Genes Cells. 11 (2006) 409-23.

[44] S. Nair, S.E. Finkel, Dps protects cells against multiple stresses during stationary phase, J. Bacteriol. 186 (2004) 4192-4198.

[45] S.Y. Ow, J. Noirel, T. Cardona, A. Taton, P. Lindblad, K. Stensjö, P.C. Wright, 2009. Quantitative overview of $\mathrm{N}_{2}$ fixation in Nostoc puntiforme ATCC 29133 through cellular enrichments and iTRAQ shotgun proteomics, Journal of Proteome Research 8 (2009) 187-198.

[46] E. Papinutto, W.G. Dundon, N. Pitulis, R. Battistutta, C. Montecucco, G. Zanotti, Structure of two iron-binding proteins from Bacillus anthracis. J. Biol. Chem. 277 (2002) 15093-15098.

[47] M.A. Quail, P. Jordan, J.M. Grogan, J.N. Butt, M. Lutz, A.J. Thomson, S.C. Andrews, J.R. Guest, Spectroscopic and voltammetric characterization of the bacterioferritin-associated ferredoxin of Escherichia coli, Biochem. Biophys. Res. Commun. 229 (1996) 635-642.

[48] B. Ren, G. Tibbelin, T. Kajino, O. Asami, R. Ladenstein, The multi-layered structure of Dps with a novel di-nuclear ferroxidase center, J. Mol. Biol. 329 (2003) 467- 477.

[49] R. Rippka, Isolation and Purification of Cyanobacteria, Methods in Enzymology. 167 (1988) $3-27$.

[50] N. Sato, T. Moriyama, M. Toyoshima, The all0458/lti46.2 gene encodes a low temperatureinduced Dps protein homologue in the cyanobacteria Anabaena sp. PCC 7120 and Anabaena variabilis M3, Microbiol.158 (2012) 2527-2536. 
[51] R. Schmidt, R. Zahn, B. Bukau, A. Mogk, ClpS is the recognition component for Escherichia coli substrates of the N-end rule degradation pathway, Mol. Microbiol. 72 (2009) 506-517.

[52] B. Schrautemeier, H. Bohme, A distinct ferredoxin for nitrogen fixation isolated from heterocysts of the cyanobacterium Anabaena variabilis, FEBS. Lett. 184 (1985) 304-308.

[53] F. Sievers, A. Wilm, D. Dineen, T.J. Gibson, K. Karplus, W. Li, R. Lopez, H. McWilliam, M. Remmert, J. Söding, Fast, scalable generation of high-quality protein multiple sequence alignments using Clustal Omega, Mol. Syst. Biol. 7 (2011) 539-544.

[54] S. Shcolnick, N. Keren, Metal homeostasis in cyanobcateria and chloroplasts, Balancing benefits and risks to the photosynthetic apparatus, Plant. Physiol. 141 (2006) 805-810.

[55] A. Shevchenko, M. Wilm, O. Vorm, M. Mann, Mass spectrometric sequencing of proteins from silver-stained polyacrylamide gels, Anal. Chem. 68 (1996) 850-858.

[56] H. Sticht, P. Rosch, The structure of iron-sulfur proteins, Prog. Biophys. Mol. Biol. 70 (1998) 95-136.

[57] C.D. Stout, Ferredoxins containing two different Fe/S centers of the forms [4Fe-4S] and [3Fe4S], Handbook of Metalloproteins, T. Poulos Ed., John Wiley \& Sons, Ltd, United Kingdom, 2001. [58] M. Su, S. Cavallo, S. Stefanini, E. Chiancone, N.D. Chasteen, The so-called Listeria innocua ferritin is a Dps protein, Iron incorporation, detoxification, and DNA protection properties. Biochemistry. 44 (2005) 5572-5578.

[59] R.G. Taylor, D.C. Walker, R.R. Mclnnes, E.coli host strains significantly affect the quality of small scale plasmid DNA preparations used for sequencing. Nucleic. Acids. Res. 21 (1993) 16771678.

[60] S.K. Weeratunga, C.E. Gee, S. Lovell, Y. Zeng, C.L. Woodin, M. Rivera, Binding of Pseudomonas aeruginosa apobacterioferritin-associated ferredoxin to bacterioferritin B promotes heme mediation of electron delivery and mobilization of core mineral iron, Biochemistry. 48 (2009) 7420-7431.

[61] M. Winkler, S. Kuhlgert, M. Hippler, T. Happe, Characterization of the key step for Lightdriven Hydrogen Evolution in Green Algae, J. Biol. Chem. 284 (2009) 36620 -36627.

[62] M. Winkler, A. Hemschemeier, J. Jacobs, S. Stripp, T. Happe, Multiple ferredoxin isoforms in Chlamydomonas reinhardtii- Their role under stress conditions and biotechnological implications, Eur. J. Cell. Biol. 89 (2010) 998-1004.

[63] S. Yasmin, S.C. Andrews, G.R. Moore, N.E. Le Brun, A new role for heme, facilitating release of iron from the bacterioferritin iron biomineral, J. Biol. Chem. 286 (2011) 3473-3483.

[64] H. Yao, Y. Wang, S. Lovell, R. Kumar, A.M. Ruvinsky, K.P. Battaile, I.A. Vakser, M. Rivera, The structure of the BfrB-Bfd complex reveals protein-protein interactions enabling iron release from bacterioferritin. J. Am. Chem. Soc. 15; 134 (2012) 13470-13481.

[65] G. Zhao, P. Ceci, A. Ilari, L. Giangiacomo, T.M. Laue, E. Chiancone, N.D. Chasteen, Iron and hydrogen peroxide detoxification properties of DNA-binding protein of Escherichia coli, J. Biol. Chem. 277 (2002) 27689-27696. 


\section{Supplementary data}

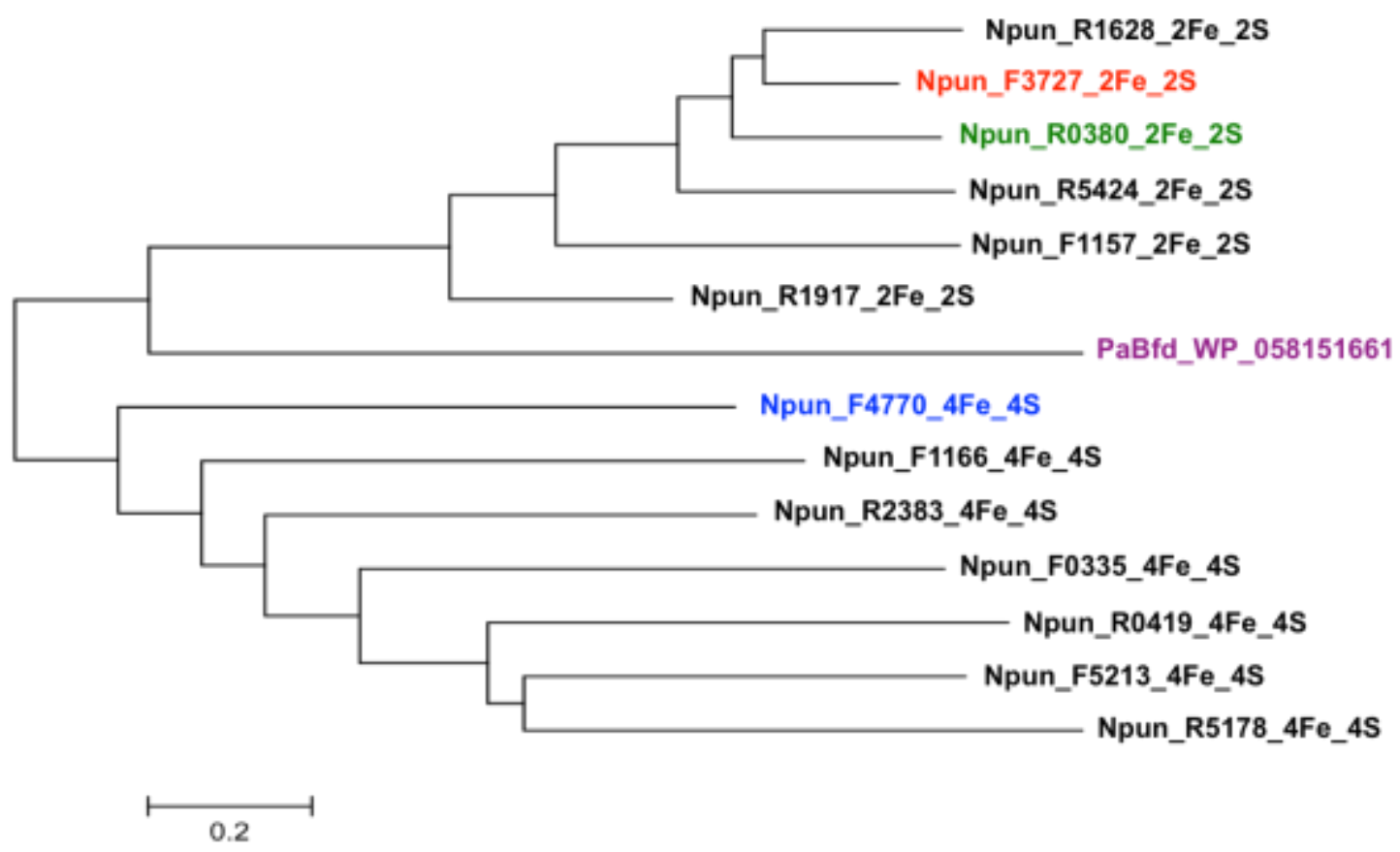

Figure S1. An unrooted phylogenetic tree of the $[2 \mathrm{Fe}-2 \mathrm{~S}]$ and $[4 \mathrm{Fe}-4 \mathrm{~S}]$ ferredoxins in $N$. punctiforme with a bootstrap support of 100 replicates. Bfd ferredoxin (WP_058151661.1) from $P$. aeruginosa, NpFdx1 (Npun_F3727), NpFdxH (Npun_R0380) and NpFdx9 (Npun_F4770) are highlighted with purple, red, green and blue colours respectively. 
Npun R5178 4Fe 4S Npun $\mathrm{r} 5213^{4} \mathrm{Fe}^{-4 S}$ Npun R2383 $4 \mathrm{Fe} 4 \mathrm{~S}$ Npun $87770.4 \mathrm{Fe} 4 \mathrm{~s}$ Npun F0335 $4 \mathrm{Fe} 43$ Npun F1166 4Fe 4S Npun R0419 4Fe 4 : Paefd WP 058151661

Npun_R5178_4Fe_4S Npun F5213 4 Fe $4 \mathrm{~S}$ Npun R2383 4Fe 43 Npun $847704 \mathrm{Fe}^{-48}$ Npun 80335 4Fe 45 Npun_r1166_4Fe_4s Npun $804194 \mathrm{Fe}^{-45}$ Palied WP 05815165.

Npun R5178 4Fe 4S Npun E5213 4Fe 4S Npun R2383 4 Fe 48 Noun 54770 4Fe 48 Npun $703354 \mathrm{Fe} 4 \mathrm{~S}$ Npun F1166 4Fe 45 Npun R0419 $4 \mathrm{Fe} 4 \mathrm{~S}$

PaBfd WP 05e151661

\section{b}

Npun R162日 2Fe $2 S$ Npun F3727 2Fo 29 Npun R0380 25e $2 \mathrm{~S}$ Npun R5424 2Fe 25 Npun F1157 2Fe 2S Npun R1917 2Fe 29 PaBfd WP 05815166

Npun R1628 2Fe $2 S$ Npun 83727 2Fe 2S Npun R0380 2Fe $2 S$ Npun RS424 2Fe 25 Npun F1157 2Fe 2S Npun R1917 2Fe $2 \mathrm{~S}$ PaBfd WP 058151661

Npun R1628 2Fe 25 Npun $\mathrm{F} 3727$ 2Fe $2 \mathrm{~S}$ Npun R0380 $2 \mathrm{Fe} 2 \mathrm{~S}$ Npun R5424 2Fe $2 \mathrm{~S}$ Npun F1157 2Fe $2 S$ Npun R1917 2Fe 25 PaBfd_WP_058151661

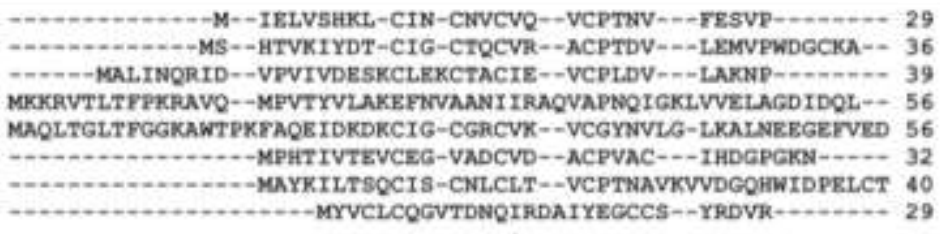

MQPPAIARQ -................-EDCQTCEMCEAYCPADALYVAPQSH--TNVAVNED 71 AQIASSPRT-...................-EDCVGCKRCETACDTDFLSIR-_....-VYLG - 70 ETGKAYMKY -...............-DECWFCLPCEKECPTNAITVQIP_....-FLLR - 75 DAAIEWMRSRIVNVSYTLGE IAIDEDVCVHCGLCTCVCPTEALTLHPET-_-YKLTFTRS 113 EDDEEIERKYMMVYS -.........-PENCIGCEACSRICPKNCYTHV -.......... AVNW - 97 AKGTDWYWID - ...........-FATCIDCGICLQVCPVEGAILAEER -...--PELQKT 73 NCVGSIHTVP ............ QCKKAGCPTCDGCVKQ-PSDYWEGWFANYNRVVAKLTNK 87 ...-EATGVG-...............-TQCGKCACLAKQVVRETINDLQSAQP--VPAFGTT 68 $+\cdot$

DLIESGTMGEYRRTLGWGYGRKONSELDTAHQLRQLPRDYQS 113

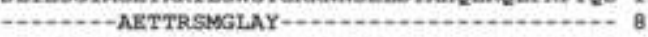

RCIVCEQCIPTCPVQAISTNL_-...................... 134

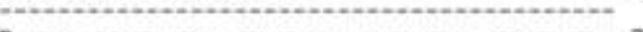

PDYWERWFOTYSOKYSEOLOKROSOSVGSEA _.......... 74

AFVAR -........................................... 73

\begin{abstract}
MA-TYKVTLKTPDE--EKTIEVSEDDYILEIANEENDMDL.PYSCNAGSCSTCAGKLISGT 57 MP-TYKVTI, INEAEGLNTTIDVEDDTYILDAA-EEAGIDLPYSCPACACSTCAGKLVSGT 58 MA-TYQVRLINKKEDIDTTIEVDEETTILEAA-EENGIELPFSCHAGSCSSCVGKVVEGE 58 MA-VYOVRFINPTLGLDRTIAVPDDQXILDIA-EDAGIRL.PSGCKOGEC SVCIAKLISGE 58 MSRTYTIKVRDRATGKTHTLKVPEDRYILHTA-EKQGVELPFSCRNGACTACAVRVLSGE 59 MPKTYTVEIDH--QGKIHTLQVPENETILSVA-DARGLELPSSCNAGVCTTCACQISQGT 57 --MYVCLCQGVTDNQIRDAIYEGCCSYRDVR-EATGVGT--QC--GKCACLAKOVVRET 52

*
\end{abstract}

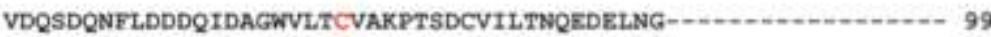
VDQGDQSFLDDDQIEAGYVLTCVAYPTSNVTIETHKEEELY VNQEDQNELDDDQVSKGYALLCVTYPRSNCTIKTHQEAYLV _.............. 99 VNQSEQKFL.RPSEIQAAYVVTCVTYPLSNCTLETHQEQVLYKSALYYKPESGKSD - -.-- 11 IYQPEAIGLSPDL.RQQGYALLCVSYPRSDLEVETQDEDEVYELQFGRYFAKGKVKAGLPL 119 VDQTDGMGVSPDLQKQGYVLLCVAKPLSDLKLETEKED TVYQLQFG -..-KDK-....- 106 LNDLQSAQPVPAFGTTAFVAA

Z: :

$\ldots$

$+\infty$

$+\cdots$

DEE 122

-

Figure S2. The multiple sequence analysis of [2Fe-2S] NpFdxs (a) and [4Fe-4S] NpFdxs (b) with

Bfrs respectively. Functional cysteines for [Fe-S] centers are marked in red. 

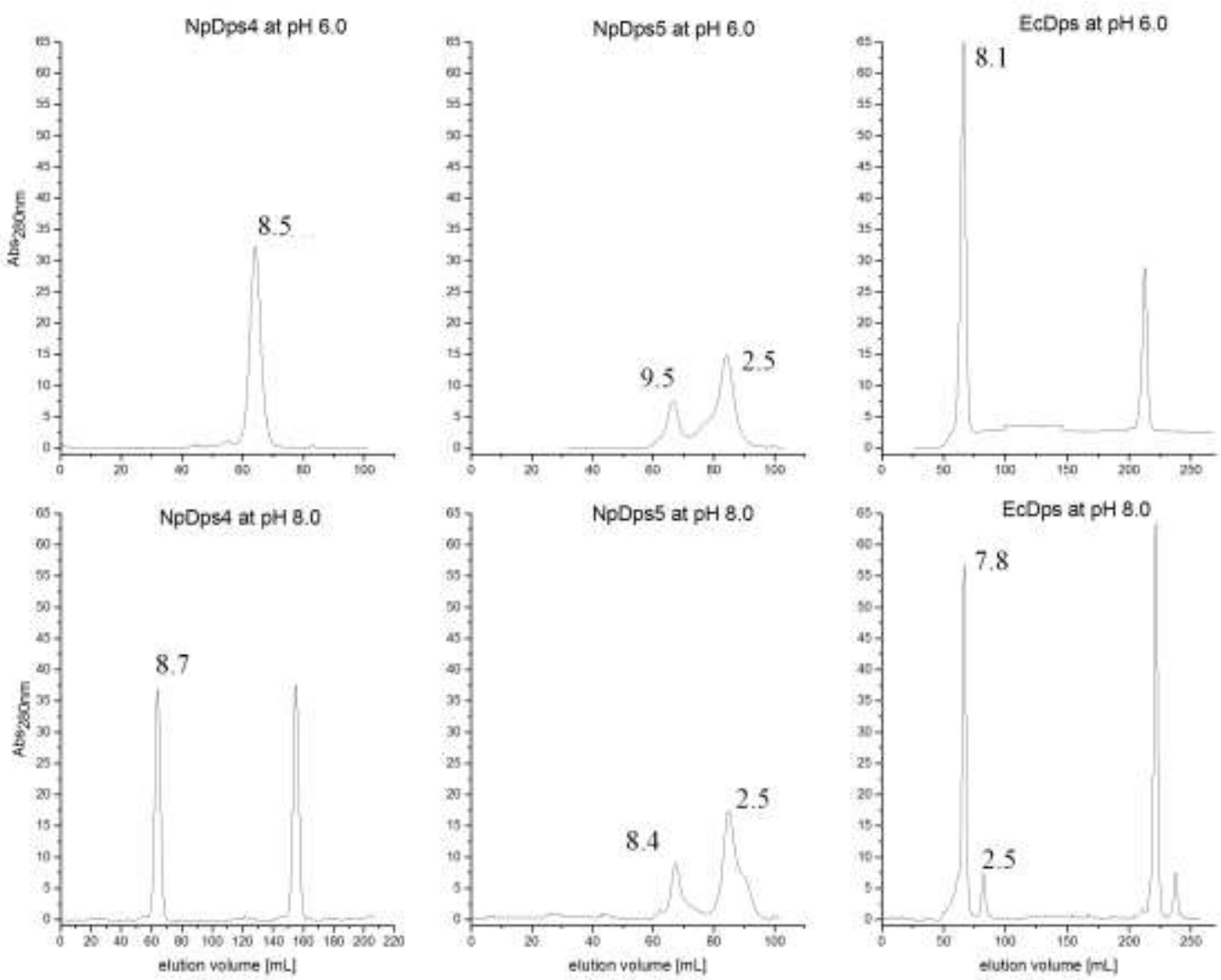

Figure S3. NpDps multimerization studied at different $\mathrm{pH}$. Gel filtration profiles of recombinant NpDps4, NpDps5 and EcDps at two pH conditions: pH 6.0 (10 mM MES, $150 \mathrm{mM} \mathrm{NaCl})$ and pH $8.0(10 \mathrm{mM}$ Tris, $150 \mathrm{mM} \mathrm{NaCl})$ at $4{ }^{\circ} \mathrm{C}$ using a HiLoad 16/600 Superdex 200 column. Proteins (ca. 0.35 - $0.5 \mathrm{mg}$ per run) were equilibrated at given conditions for at least $30 \mathrm{~min}$ prior gel filtration at $4{ }^{\circ} \mathrm{C}$. The absorption units at $280 \mathrm{~nm}$ are in mAU. For EcDps at both $\mathrm{pH}$ conditions and for NpDps 4 at $\mathrm{pH} 8.0$ two subsequent injections are shown. Numbers adjacent to the major peaks represent calculated multimeric state (only once annotated for each chromatogram) of the Dps with standard deviations below $5 \%$. EcDps served as a control for NpDps multimerization. 


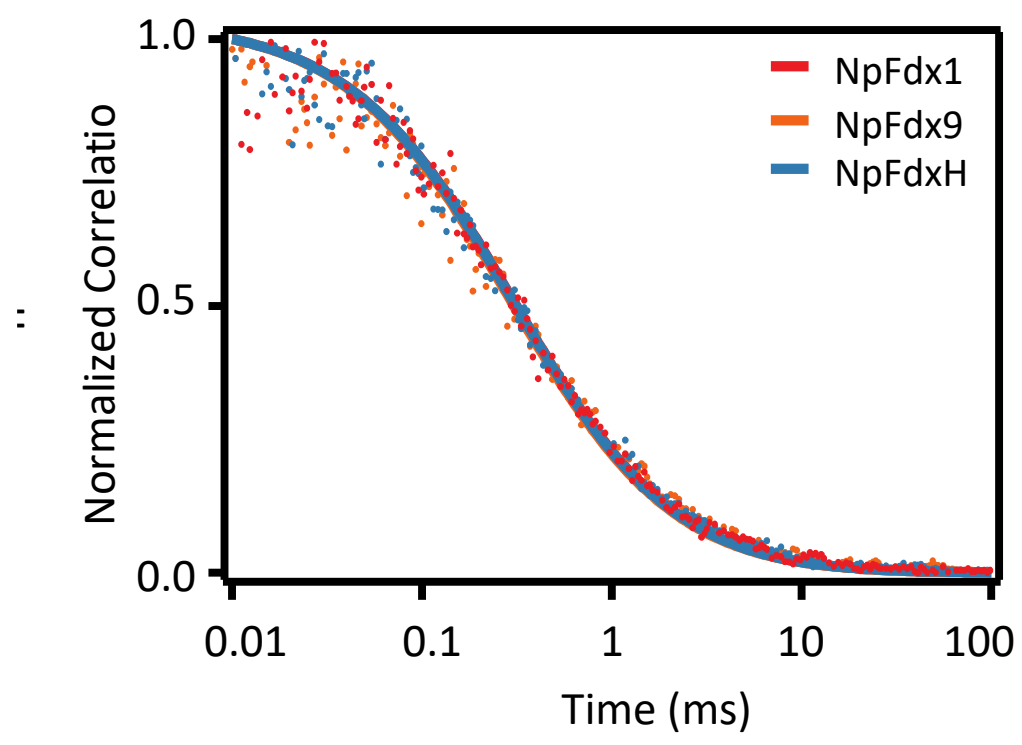

Figure S4. Normalized FCS correlation traces of the NpFdx1, NpFdx9 and NpFdxH at pH 6.0. In all cases a control experiment measuring the diffusion time of Atto647N free dye was calculated. Triplet state populations considered that were less than $10 \%$. 
a

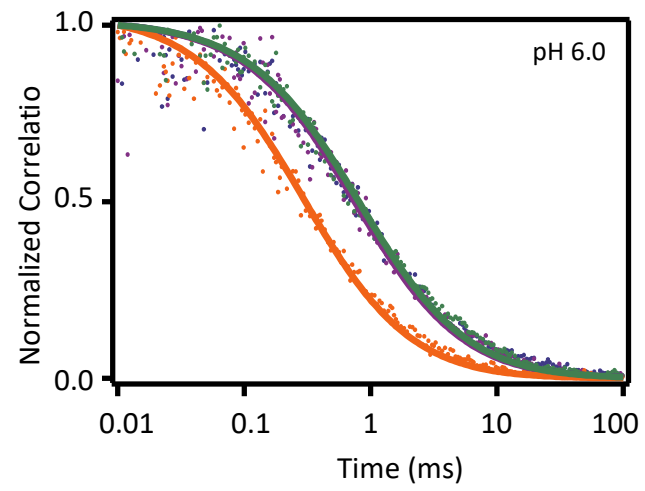

b

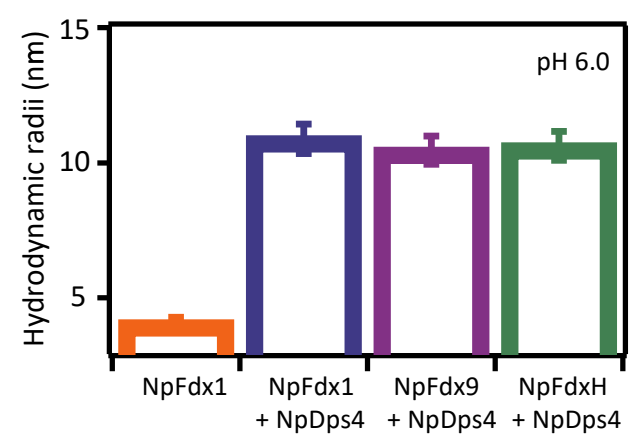

e

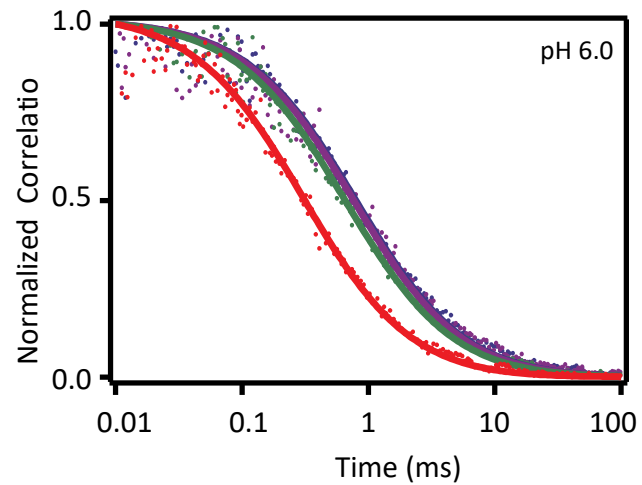

g

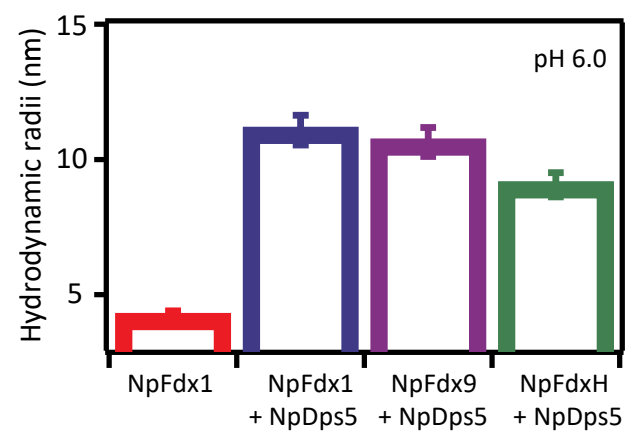

- NpFdx1

- NpFdx1 - NpDps4

- NpFdx9 - NpDps4

C

- NpFdxH - NpDps4

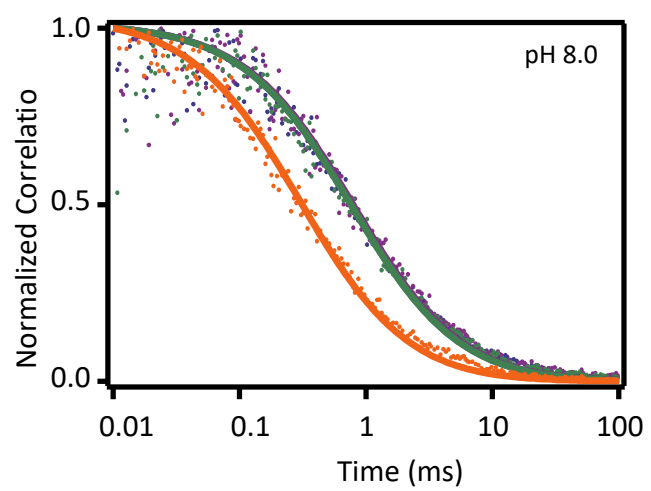

d

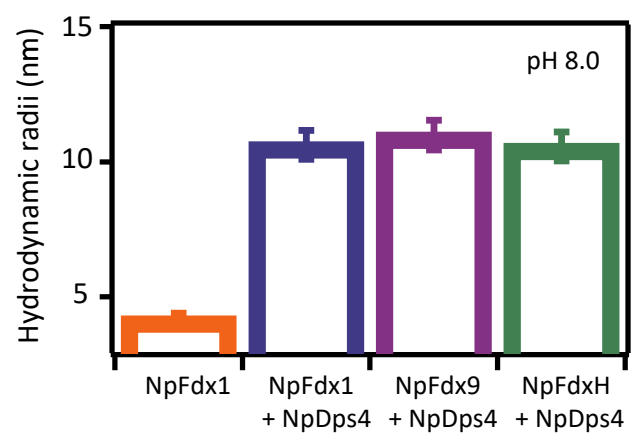

- NpFdx1

- NpFdx1 - NpDps5

- NpFdx9 - NpDps5

- NpFdxH - NpDps5

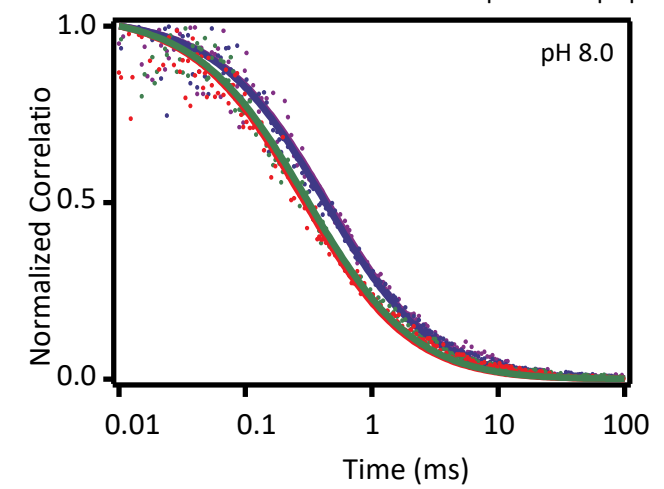

$\mathrm{h}$

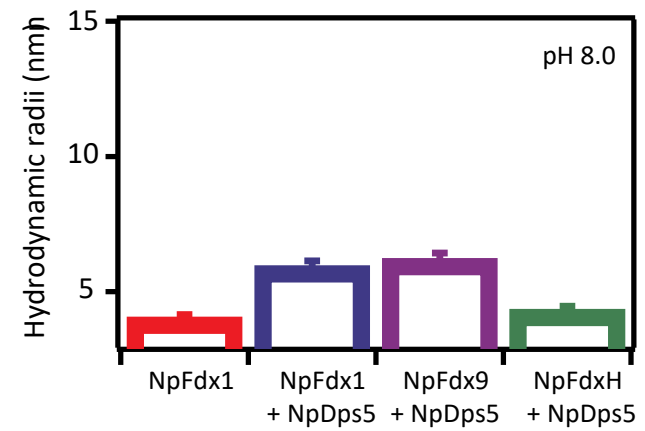


Figure S5. FCS traces of NpFdx1, NpFdx 9 and NpFdxH with NpDps4 and with NpDps5 at different $\mathrm{pH}$ conditions ( $\mathrm{pH} 6.0$ and 8.0). Normalized FCS correlation traces and corresponding apparent hydrodynamic radius of the $\mathrm{NpFdx} 1, \mathrm{NpFdx} 9$ and $\mathrm{NpFdxH}$ in the presence of the $\mathrm{NpDps} 4$ at $\mathrm{pH}$ 6.0 (a \& b) and pH 8.0 (c \& d) respectively. Normalized FCS correlation traces and corresponding apparent hydrodynamic radii of the NpFdx1, NpFdx9 and $\mathrm{NpFdxH}$ in the presence of the NpDps5 at pH $6.0(\mathrm{a} \& \mathrm{~b})$ and $8.0(\mathrm{c} \& \mathrm{~d})$ respectively. All FCS traces are in comparison with the NpFdxs alone accordingly. All experiments were carried out at $21^{\circ} \mathrm{C}$. 

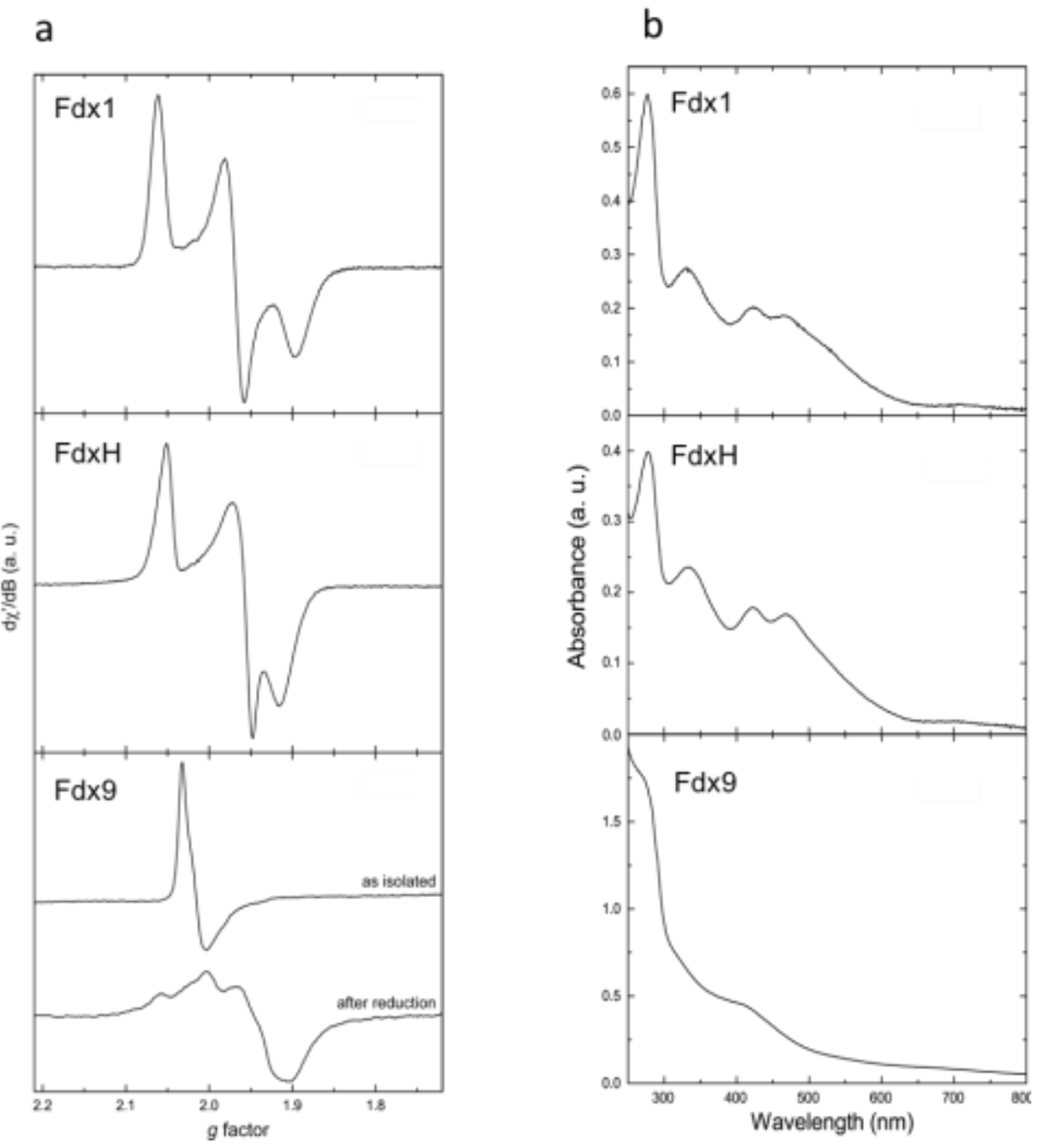

Figure S6. UV-visible and electron paramagnetic resonance spectra of $\mathrm{NpFdx} 1, \mathrm{NpFdxH}$ and NpFdx9 proteins. NpFdx1 $(100 \mu \mathrm{M})$ after chemical reduction with dithionite $(\mathrm{T}=15 \mathrm{~K}, 32 \mu \mathrm{W})$, $\mathrm{NpFdxH}(185 \mu \mathrm{M})$ after chemical reduction with dithionite $(\mathrm{T}=15 \mathrm{~K}, 32 \mu \mathrm{W})$ and $\mathrm{NpFdx} 9(33$ $\mu \mathrm{M})$ as isolated $(\mathrm{T}=7 \mathrm{~K}, 2 \mathrm{~mW})$ and after reduction with dithionite $(\mathrm{T}=11 \mathrm{~K}, 2 \mathrm{~mW})$ are presented in upper, middle and lower parts in the panel a. Reduced $\mathrm{NpFdx1}$ and $\mathrm{NpFdxH}$ present spectra characteristic of $[2 \mathrm{Fe}-2 \mathrm{~S}]$ centers. NpFdx9 presents a minor population of [3Fe-4S] centers in its as-isolated state, and [4Fe-4S] centers after reduction. UV-visible spectra of as-isolated NpFdx1, $\mathrm{NpFdxH}$ and $\mathrm{NpFdx} 9$ proteins are presented in upper, middle and lower parts in the panel b. NpFdx 1 and $\mathrm{NpFdxH}$ present UV-visible spectra characteristic for [2Fe-2S] proteins. NpFdx9 presents broad bands in the near UV-visible regions suggesting the presence of [3Fe-4S] and/or [4Fe-4S] centers. 